\title{
Is Capital Punishment Morally Required? The Relevance of Life-Life Tradeoffs
}

\section{Citation}

Cass R. Sunstein \& Adrian Vermeule, Is Capital Punishment Morally Required? The Relevance of Life-Life Tradeoffs (John M. Olin Program in Law and Economics Working Paper No. 239, 2005).

\section{Published Version}

http://chicagounbound.uchicago.edu/law_and_economics/287/

\section{Permanent link}

http://nrs.harvard.edu/urn-3:HUL.InstRepos:12809433

\section{Terms of Use}

This article was downloaded from Harvard University's DASH repository, and is made available under the terms and conditions applicable to Other Posted Material, as set forth at http:// nrs.harvard.edu/urn-3:HUL.InstRepos:dash.current.terms-of-use\#LAA

\section{Share Your Story}

The Harvard community has made this article openly available.

Please share how this access benefits you. Submit a story.

\section{Accessibility}




\section{University of Chicago Law School Chicago Unbound}

Coase-Sandor Working Paper Series in Law and

Economics

Coase-Sandor Institute for Law and Economics

2005

\section{Is Capital Punishment Morally Required? The Relevance of Life-Life Tradeoffs}

Cass R. Sunstein

Adrian Vermeule

Follow this and additional works at: http://chicagounbound.uchicago.edu/law_and_economics Part of the Law Commons

\section{Recommended Citation}

Cass R. Sunstein \& Adrian Vermeule, "Is Capital Punishment Morally Required? The Relevance of Life-Life Tradeoffs" (John M. Olin Program in Law and Economics Working Paper No. 239, 2005).

This Working Paper is brought to you for free and open access by the Coase-Sandor Institute for Law and Economics at Chicago Unbound. It has been accepted for inclusion in Coase-Sandor Working Paper Series in Law and Economics by an authorized administrator of Chicago Unbound. For more information, please contact unbound@law.uchicago.edu. 


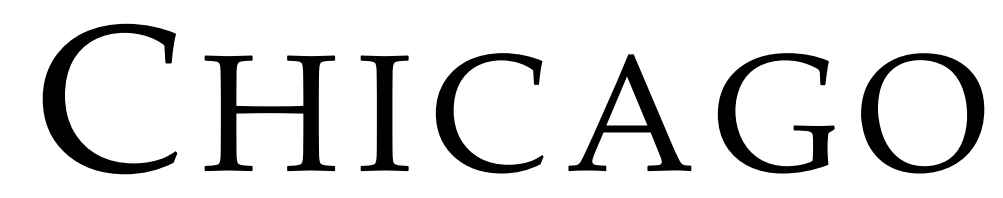

JOHN M. Olin LAW \& ECONOMICS WORKING PAPER NO. 239

(2D SERIES)

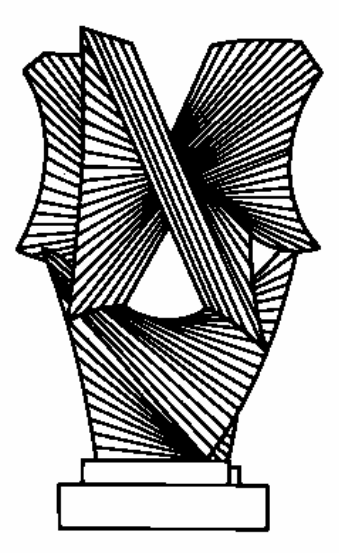

\title{
Is Capital Punishment Morally Required? The Relevance of Life-Life Tradeoffs
}

Cass R. Sunstein and Adrian Vermeule

\author{
THE LAW SCHOOL \\ THE UNIVERSITY OF CHICAGO
}

March 2005

This paper can be downloaded without charge at:

The Chicago Working Paper Series Index: http://www.law.uchicago.edu/Lawecon/index.html and at the Social Science Research Network Electronic Paper Collection:

http://ssrn.com/abstract_id=691447 
Preliminary draft 3/22/05

Not for citation, circulation, or quotation without express permission

All rights reserved

\title{
Is Capital Punishment Morally Required? The Relevance of Life-Life Tradeoffs
}

\author{
Cass R. Sunstein ${ }^{*}$ \\ Adrian Vermeule $^{* *}$
}

\begin{abstract}
Recent evidence suggests that capital punishment may have a significant deterrent effect, preventing as many eighteen or more murders for each execution. This evidence greatly unsettles moral objections to the death penalty, because it suggests that a refusal to impose that penalty condemns numerous innocent people to death. Capital punishment thus presents a life-life tradeoff, and a serious commitment to the sanctity of human life may well compel, rather than forbid, that form of punishment. Moral objections to the death penalty frequently depend on a distinction between acts and omissions, but that distinction is misleading in this context, because government is a special kind of moral agent. The familiar problems with capital punishmentpotential error, irreversibility, arbitrariness, and racial skew- do not argue in favor of abolition, because the world of homicide suffers from those same problems in even more acute form. The widespread failure to appreciate the life-life tradeoffs involved in capital punishment may depend on cognitive processes that fail to treat "statistical lives" with the seriousness that they deserve.
\end{abstract}

Many people believe capital punishment is morally impermissible. In their view, executions are inherently cruel and barbaric. ${ }^{1}$ Often they add that capital punishment is not, and cannot be, imposed in a way that adheres to the rule of law. ${ }^{2}$ They contend that as administered, capital punishment ensures the execution of (some) innocent people, and also that it reflects arbitrariness, in the form of random or invidious infliction of the ultimate penalty. ${ }^{3}$

\footnotetext{
*Karl N. Llewellyn Distinguished Service Professor of Jurisprudence, The University of Chicago Law School, Department of Political Science and the College.

${ }^{* *}$ Bernard D. Meltzer Professor of Law, The University of Chicago. The authors thank Robert Hahn, Dan Kahan, Steven Levitt, Richard Posner, and Eugene Volokh for helpful suggestions, and Blake Roberts for excellent research assistance and valuable comments.

${ }^{1}$ See, e.g., Furman v. Georgia, 408 U.S. 238, 371 (1972) (Marshall, J., concurring).

${ }^{2}$ See Stephen B. Bright, Why the United States Will Join the Rest of the World in Abandoning Capital Punishment, in Debating the Death Penalty 152 (Hugo Bedau \& Paul Cassell eds. 2004).

${ }^{3}$ See, e.g., James LeibMAn ET AL., A BROKEn SyStem: ERROR RATES IN CAPITAL CASES, 1973 - 1995 (Columb. L. School, Pub. L. Res. Paper No. 15, 2000).
} 
Defenders of capital punishment come in two different camps. Some are retributivists. ${ }^{4}$ Following Kant, they claim that for the most heinous forms of wrongdoing, the penalty of death is morally justified or perhaps even required. Other defenders of capital punishment are consequentialists and often also welfarists. ${ }^{5}$ They contend that the deterrent effect of capital punishment is significant and that it justifies the infliction of the ultimate penalty. Consequentialist defenses of capital punishment, however, tend to assume that capital punishment is (merely) morally permissible, as opposed to being morally obligatory.

Our goal here is to suggest that the debate over capital punishment is rooted in an unquestioned assumption, and that the failure to question that assumption is a serious moral error. The assumption is that for governments, acts are morally different from omissions. We want to raise the possibility that an indefensible form of the act-omission distinction is crucial to the most prominent objections to capital punishment-and that defenders of capital punishment, apparently making the same distinction, have failed to notice that on the logic of their theory, capital punishment is morally obligatory, not just permissible. We want to suggest, in other words, that capital punishment may be morally required not for retributive reasons, but in order to prevent the taking of innocent lives. ${ }^{6}$

The suggestion bears not only on moral and political debates, but also on constitutional questions. In invalidating the death penalty for juveniles, for example, the Supreme Court did not seriously engage the possibility that capital punishment for juveniles may help to prevent the death of innocents, including the deaths of juvenile innocents. ${ }^{7}$ And if our suggestion is correct, it is connected to many questions outside of

\footnotetext{
4 See, e.g., Luis Pojman, Why the Death Penalty is Morally Permissible, in DeBAting THE DeAth PenAlty 51, 55-58 (Hugo Bedau \& Paul Cassell eds. 2004).

${ }^{5}$ Arguments along these lines can be found in id. at 58-73.

${ }^{6}$ In so saying, we are suggesting the possibility that states are obliged to maintain the death penalty, not that they must inflict that penalty is every individual case of a specified sort; hence we are not attempting to enter into the debate over mandatory death sentences, as invalidated in Woodson v North Carolina, 428 US 280 (1986); Lockett v. Ohio, 438 US 586 (1978). For relevant discussion, see Martha Nussbaum, Equity and Mercy, 22 Phil \& Pub Aff 83 (1993).

${ }^{7}$ Roper v. Simmons, 125 US 1183 (2005). Here is the heart of the Court's discussion: “As for deterrence, it is unclear whether the death penalty has a significant or even measurable deterrent effect on juveniles, as counsel for the petitioner acknowledged at oral argument. . . . [T] is of special concern because the same characteristics that render juveniles less culpable than adults suggest as well that juveniles will be less susceptible to deterrence. . . . To the extent the juvenile death penalty might have residual deterrent effect, it is worth noting that the punishment of life imprisonment without the possibility of parole is itself a severe sanction, in particular for a young person.” These are speculations at
} 
the context of capital punishment. If omissions by the state are often indistinguishable, in principle, from actions by the state, then a wide range of apparent failures to act-in the context not only of criminal and civil law, but of regulatory law as well—should be taken to raise serious moral and legal problems. Those who accept our arguments in favor of the death penalty may or may not welcome the implications for government action in general. In many situations, ranging from environmental quality to highway safety to relief of poverty, our arguments suggest that in light of imaginable empirical findings, government is obliged to provide far more protection than it now does, and that it should not be permitted to hide behind unhelpful distinctions between acts and omissions.

The foundation for our argument is a large and growing body of evidence that capital punishment may well have a deterrent effect, possibly a quite powerful one. A leading study suggests that each execution prevents some eighteen murders, on average. ${ }^{8}$ The particular numbers do not much matter. If the current evidence is even roughly correct, then a refusal to impose capital punishment will effectively condemn numerous innocent people to death. States that choose life imprisonment, when they might choose capital punishment, are ensuring the deaths of a large number of innocent people. ${ }^{9}$ On moral grounds, a choice that effectively condemns large numbers of people to death seems objectionable to say the least. For those who are inclined to be skeptical of capital punishment for moral reasons - a group that includes one of the current authors-the task is to consider the possibility that the failure to impose capital punishment is, prima facie and all things considered, a serious moral wrong.

Judgments of this sort are often taken to require a controversial commitment to either a consequentialist or a deontological view about the foundations of moral

best, and they do not engage with the empirical literature; of course, that literature does not dispose of the question whether juveniles are deterred by the death penalty.

${ }^{8}$ See Hashem Dezhbakhsh et al., , Does Capital Punishment Have a Deterrent Effect? New Evidence from Postmoratorium Panel Data, 5 AM. L. \& ECON. ReV 344, 344 (2003). In what follows, we will speak of executions saving eighteen lives on average. We are of course suppressing many issues in that formulation, simply for expository convenience. For one thing, that statistic is a national average, as we emphasize in Part IV. For another thing, future research might find that capital punishment has diminishing returns: if the first 100 executions deter 1800 murders, it does not follow that another 1,000 executions will deter another 18,000 murders. We will take these and like qualifications as understood in the discussion that follows.

${ }^{9}$ In recent years, the number of murders in the United States has fluctuated between 15,000 and 24,000. Federal Bureau of Investigation, Crime in the United States: 2003 Tabl.1 (2003), available at http://www.fbi.gov/ucr/03cius.htm. 
evaluation. One of our principal points, however, is that the choice between consequentialist and deontological approaches to morality does not seem crucial here; we will suggest that on certain empirical assumptions, theorists of both stripes might converge on the idea that capital punishment is morally obligatory. On consequentialist grounds, the death penalty seems morally obligatory if it is the only or most effective means of preventing significant numbers of murders; and much of our discussion will emphasize this point. For deontologists, a killing is a wrong under most circumstances, and its wrongness does not depend on its consequences or its effects on overall welfare. Many deontologists (of course not all) believe that capital punishment counts as a moral wrong. But in the abstract, any deontological injunction against the wrongful infliction of death turns out to be indeterminate on the moral status of capital punishment if it is necessary to prevent significant numbers of killings.

An unstated assumption animating much opposition to capital punishment, especially among self-conscious or intuitive deontologists, is that capital punishment counts as an "act," while the refusal to impose it counts as an "omission," and that the two are altogether different from the moral point of view. We shall investigate this claim in some detail. But we doubt that the act-omission distinction can bear the moral weight given to it by the critics of capital punishment. Whatever its value as a moral concept where individuals are concerned, the act-omission distinction misfires in the general setting of government regulation. If government policies fail to protect people against air pollution, occupational risks, or racial discrimination, it is inadequate to put great moral weight on the idea that the failure to act is a mere "omission." No one believes that government can avoid responsibility to protect people against serious dangers, as for example by refusing to enforce regulatory statutes, simply by contending that such refusals are unproblematic omissions. ${ }^{10}$ If state governments impose light penalties on offenders, or treat certain offenses (say, domestic violence) as unworthy of attention, they should not be able to escape public retribution by contending that they are simply refusing to act. Where government is concerned, failures of protection, through refusals

\footnotetext{
${ }^{10}$ Indeed, agency inaction is frequently subject to judicial review. See Ash Bhagwat, Three-Branch Monte, 72 Notre Dame L Rev 157 (1996).
} 
to punish and deter private misconduct, cannot be justified by pointing to the distinction between acts and omissions.

It has even become common to speak of "risk-risk tradeoffs," understood to arise when regulation of one risk (say, the risks associated with use of DDT) gives rise to another risk (say, the spread of malaria, against which DDT has been effective). ${ }^{11}$ Or suppose that an air pollutant creates adverse health effects but also has health benefits, as appears to be the case for ground-level ozone. ${ }^{12}$ No one believes that for moral reasons, social planners should refuse to take account of such tradeoffs; there is general agreement that whether a particular substance ought to be regulated depends on the overall effect of regulation on human well-being.

As an empirical matter, criminal law is pervaded by its own risk-risk tradeoffs. If the deterrent signal works, a failure to impose stringent penalties on certain crimes will increase the number of those crimes. A refusal to impose such penalties is, for that reason, problematic from the moral point of view. The very idea of "equal protection of the laws," in its oldest and most literal sense, attests to the importance of enforcing the criminal and civil law so as to safeguard the potential victims of private violence. ${ }^{13}$ What we are suggesting is that the death penalty produces a risk-risk tradeoff of its own, indeed what we will call a life-life tradeoff, to the extent that a refusal to impose capital punishment yields a significant increase in the number of deaths of innocent people.

Of course this point does not resolve the capital punishment debate. By itself, the act of execution may be a wrong, in a way that cannot be said for an act of imposing civil or criminal penalties on (say) environmental degradation. But the existence of life-life tradeoffs raises the possibility that for those who oppose killing, a rejection of capital punishment is not necessarily mandated. On the contrary, it may well be morally compelled. At the very least, those who object to capital punishment, and do so in the name of protecting life, must come to terms with the fact that the failure to inflict capital punishment might fail to protect life-and must, in our view, justify their position in

\footnotetext{
${ }^{11}$ See generally RISK VERSUS RISK: TRADEOFFs In PROTECTING HEALTH AND THE ENVIRONMENT (John D. Graham \& Jonathan Baert Wiener eds.1995).

12 See Am. Trucking Assocs., Inc. v. E.P.A., 175 F.3d 1027, 1051 - 53 (D.C. Cir. 1999).

${ }^{13}$ See Randall Kennedy, Race, Crime, and the Law (1997).
} 
ways that do not rely on question-begging claims about the distinction between acts and omissions.

We begin, in Part I, with the facts. Contrary to widely-held beliefs, based on partial information or older studies, a wave of recent evidence suggests the possibility that capital punishment saves lives. One study finds that as a national average, each execution deters some eighteen murders. Our question whether capital punishment is morally obligatory is motivated by these findings; our central concern is that foregoing any given execution may be equivalent to condemning some eighteen unidentified people to a premature and violent death. Of course social science can always be disputed in this contentious domain, and we mean to outline, rather than to defend, the relevant evidence here. But the current findings do provide evidence of deterrence, and we think that it is illuminating to take those findings as given for purposes of analysis of the moral issues. Those who would like to abolish capital punishment, and who reject the social science, might find it useful to ask whether they would maintain their commitment to abolition if they were persuaded that capital punishment does have a strong deterrent effect; that is the principal issue that we mean to raise here.

In Part II, the centerpiece of the paper, we offer a few remarks on moral foundations and examine some standard objections to capital punishment that might seem plausible even in light of the current findings. We focus in particular on the crucial view that capital punishment is objectionable because it requires affirmative and intentional state "action,” not merely an “omission.” That distinction, we suggest, systematically misfires when applied to government, which is a moral agent with distinctive features. The act-omission distinction may not even be intelligible in the context of government, which always faces a choice among policy regimes, and in that sense cannot help but "act."

Even if the distinction between acts and omissions can be rendered intelligible in regulatory settings, its moral relevance is obscure. Some acts are morally obligatory, while some omissions are morally culpable. If capital punishment has significant deterrent effects, we suggest that for government to omit to impose it is morally blameworthy, even on a deontological account of morality. Deontological accounts typically recognize a consequentialist override to baseline prohibitions; if each execution 
saves eighteen lives, on average, then it is plausible to think that the override is triggered, in turn triggering an obligation to adopt capital punishment.

Once the act/omission distinction is rejected where government is concerned, it becomes clear that the most familiar, and plausible, objections to capital punishment deal with only one side of the ledger: the objections fail to take account of the exceedingly arbitrary deaths that capital punishment apparently deters. We consider rule-of-law concerns about the irreversibility of capital punishment and its possibly random or invidious administration; a strict-scrutiny principle that capital punishment should not be permitted if other means for producing the same level of deterrence are available; and concerns about slippery slopes from capital punishment to other practices. We suggest that while some of these complaints have merit, they do not count as decisive objections to capital punishment, because they embody a flawed version of the act-omission distinction, and generally overlook the fact that the moral objections to capital punishment apply even more strongly to the murders that capital punishment deters.

In Part III, we conjecture that various cognitive and social mechanisms, lacking any claim to moral relevance, cause many individuals and groups to subscribe to untenable versions of the distinction between acts and omissions, or to underestimate the life-saving benefits of capital punishment while exaggerating the harms that it causes. An important concern here is a sort of misplaced concreteness, stemming from heuristics such as salience and availability. The single person executed is often more visible and more salient in public discourse than are the (on average) eighteen abstract statistical persons whose murders a single execution would deter. If those people, and their names and faces, were highly visible, we suspect that many of the objections to capital punishment would at least be shaken. As environmentalists have often argued, "statistical persons" should not be treated as irrelevant abstractions. ${ }^{14}$ The point holds for criminal justice no less than for pollution controls.

Part IV expands upon the implications of our view and examines some unresolved puzzles. Here we emphasize that we hold no brief for capital punishment across all contexts, or in the abstract. The crucial question is what the facts show in particular domains. We mean to include here a plea for a disaggregated approach. The evidence that

\footnotetext{
${ }^{14}$ Lisa Heinzerling, The Rights of Statistical People, 24 HARV. ENV. L. REV. 189, 189 (2000).
} 
capital punishment strongly deters murder is aggregate evidence based on national averages; future research and resulting policies would do well to take separate account of various regions and of various classes of offenders and offenses. We also emphasize that our argument is limited to the setting of life-life tradeoffs — settings in which the taking of a life by the state will reduce the number of lives taken overall. We express no view about cases in which that condition does not hold-for example, the possibility of capital punishment for serious offenses other than killing, with rape being the principal historical example, and with rape of children being a currently contested problem. Such cases involve distinctively difficult moral problems that we mean to bracket here. A brief conclusion follows.

\section{Evidence}

For many years, the deterrent effect of capital punishment was sharply disputed. ${ }^{15}$ But a great deal of recent evidence strengthens the claim that capital punishment has large deterrent effects. ${ }^{16}$ The reason for the shift is that a wave of sophisticated econometric studies have exploited a newly-available form of data, so-called "panel data" that uses all information from a set of units (states or counties) and follows that data over an extended period of time. A leading study used county-level panel data from 3,054 U.S. counties between 1977 and 1996. ${ }^{17}$ The authors find that the murder rate is significantly reduced by both death sentences and executions. The most striking finding is that on average, each execution results in 18 fewer murders. ${ }^{18}$

Other econometric studies also find a substantial deterrent effect. In two papers, Paul Zimmerman uses state-level panel data from 1978 onwards to measure the deterrent effect of execution rates and execution methods. He estimates that each execution deters

\footnotetext{
${ }^{15}$ Compare, e.g., Isaac Ehrlich, The Deterrent Effect of Capital Punishment: A Question of Life and Death, 65 Am. ECON. REV. 397, 398 (1975) (estimating each execution deters eight murders); with William J. Bowers \& Glenn L. Pierce, The Illusion of Deterrence in Isaac Ehrlich's Research on Capital Punishment, 85 YALE L.J. 187, 187 (1975) (finding Ehrlich's data and methods unreliable).

${ }^{16}$ Even as this evidence was being developed, one of us rashly and wrongly predicted that the debate would remain inconclusive for the foreseeable future. See Adrian Vermeule, Interpretive Choice, 75 N.Y.U. L. REV. 74, 100-101(2000).

${ }^{17}$ See Dezhbakhsh et al., supra note 8, at 359.

${ }^{18}$ Id. at 373.
} 
an average of fourteen murders. ${ }^{19}$ Using state-level data from 1977 to 1997, Mocan and Gittings find that each execution deters five murders on average. ${ }^{20}$ They also find that increases in the murder rate come from removing people from death row and also from commutations in death sentences. Yet another study, based on state-level data from 19971999, finds that a death sentence deters 4.5 murders and an execution deters three murders. $^{21}$ The same study investigates the question whether executions deter crimes of passion and murders by intimates. The answer is clear: these categories of murder are deterred by capital punishment. ${ }^{22}$ The deterrent effect of the death penalty is also found to be a function of the length of waits on death row, with a murder deterred for every 2.75 years of reduction in the period before execution. ${ }^{23}$

In the period between 1972 and 1976, the Supreme Court produced an effective moratorium on capital punishment, and an extensive study exploits that fact to estimate the deterrent effect. Using state-level data from 1960-2000, the authors make before-andafter comparisons, focusing on the murder rate in each state before and after the death penalty was suspended and reinstated. ${ }^{24}$ The authors find a substantial deterrent effect. After suspending the death penalty, 91\% of states faced an increase in homicides-and in $67 \%$ of states, the rate was decreased after reinstatement of capital punishment. ${ }^{25}$

\footnotetext{
${ }^{19}$ Paul R. Zimmerman, Estimates of the Deterrent Effect of Alternative Execution Methods in the United States, Am. J. Econ. \& Soc. (forthcoming); Paul R. Zimmerman, State Executions, Deterrence, and the Incidence of Murder, 7 J. APPLIED ECON. 163, 163 (2004).

${ }^{20}$ H. Naci Mocan \& R. Kaj Gittings, Getting Off Death Row: Commuted Sentences and the Deterrent Effect of Capital Punishment, 46 J. L. \& Econ. 453, 453 (2003). Notably, no clear evidence of a deterrent effect from capital punishment emerges from Lawrence Katz et al., Prison Conditions, Capital Punishment, and Deterrence, $5 \mathrm{Am} \mathrm{L}$ and Ec Rev 318, 330 (2003), which finds that the estimate of deterrence is extremely sensitive to the choice of specification, with the largest estimate paralleling that in Ehrlich, supra note. Note, however, that the principal finding in id. is that prison deaths do have a strong deterrent effect, and a stunningly large one - with each prison death producing a reduction of "30-100 violent crimes and a similar number of property crimes.” Id. at 340.

21 Joanna M. Shepherd, Murders of Passion, Execution Delays, and the Deterrence of Capital Punishment, 33 J. Legal Stud. 283, 308 (2004).

${ }^{22} I d$. at 305 ("Many researchers have argued that some types of murders cannot be deterred: they assert that murders committed during arguments or other crime-of-passion moments are not premeditated and therefore undeterrable. My results indicate that this assertion is wrong: the rates of crime-of-passion and murders by intimates - crimes previously believed to be undeterrable - all decrease in execution months.”).

${ }^{23} I d$. at 283.

${ }^{24}$ Id.

${ }^{25} \mathrm{Id}$. at tables 5 \& 6.
} 
A recent study offers more refined findings. ${ }^{26}$ Disaggregating the data on a state by state basis, Joanna Shepherd finds that the nation-wide deterrent effect of capital punishment is entirely driven by only six states_and that no deterrent effect can be found in the twenty-one other states that have restored capital punishment. ${ }^{27}$ What distinguishes the six from the twenty-one? The answer lies in the fact that states showing a deterrent effect are executing more people than states that do not. In fact the data show a "threshold effect": deterrence is found in states that had at least nine executions between 1977 and 1996. In states below that threshold, no deterrence can be found. ${ }^{28}$ This finding is intuitively plausible. Unless executions reach a certain level, murderers may act as if the death is so improbable as not to be worthy of concern. ${ }^{29}$ Her main lesson is that once the level of executions reaches a certain level, the deterrent effect of capital punishment is substantial.

All in all, the recent evidence of a deterrent effect from capital punishment seems impressive. But in studies of this kind, it is hard to control for confounding variables, and a degree of doubt inevitably remains. It remains possible that these findings will be exposed as statistical artifacts or will be found to rest on flawed econometric methods. More broadly, skeptics are likely to question the mechanisms by which capital punishment has a deterrent effect. On the skeptical view, many murderers lack a clear sense of the likelihood and perhaps even the existence of executions in their state; further problems for the deterrence claim are introduced by the fact that capital punishment is imposed infrequently and after long delays. ${ }^{30}$ In any case many murders are committed in a passionate state that does not lend itself to an all-things-considered analysis on the part of perpetrators.

As mentioned above, and as we discuss in Part IV, these suppositions are in some tension with existing evidence. But let us suppose that these doubts are reasonable. If so,

\footnotetext{
${ }^{26}$ JoAnna M. Shepherd, Deterrence Versus Brutalization: Capital Punishment's Differing IMPACTS AMONG STATES (Emory Legal Scholarship Working Paper No. 1, 2004).

${ }^{27} I d$. at 38.

${ }^{28}$ Id. at $36-38$.

${ }^{29}$ Less intuitively, Shepherd finds that in thirteen of the states that had capital punishment, but executed few people, capital punishment actually increased the murder rate. She attributes this puzzling result to what she calls the "brutalization effect," by which capital punishment devalues human life and teaches people about the legitimacy of vengeance. Id. at $37-38$.

${ }^{30}$ See Steven Levitt, Understanding Why Crime Fell in the 1990s, 18 J Econ Persp 163 (2004).
} 
should current findings be deemed irrelevant for purposes of policy and law? That would be an odd conclusion. In regulation as a whole, it is common to embrace some version of the Precautionary Principle ${ }^{31}$ - the idea that steps should be taken to prevent significant harm even if cause-and-effect relationships remain unclear and even if the risk is not likely to come to fruition. Even if we reject strong versions of the Precautionary Principle, ${ }^{32}$ it hardly seems sensible that governments should ignore evidence demonstrating a significant possibility that a certain step will save large numbers of innocent lives.

For capital punishment, critics often seem to assume that evidence on deterrent effects should be ignored if reasonable questions can be raised about it. But as a general rule, this is implausible. In most contexts, the existence of reasonable questions is hardly an adequate reason to ignore evidence of severe harm. If it were, many environmental controls would be in serious jeopardy. ${ }^{33}$ We do not mean to suggest that government should commit what many people consider to be, prima facie, a serious moral wrong simply on the basis of speculation that this step will do some good. But a degree of reasonable doubt does not seem sufficient to doom capital punishment, if the evidence suggests that significant deterrence occurs.

In any event, we will proceed by stipulating to the validity of this evidence, in order to isolate the question of its moral significance. Our primary concern here is not to reach a final judgment about the evidence, but how to evaluate capital punishment given the assumption of a substantial deterrent effect. Those who doubt the evidence might ask themselves how they would assess the moral questions if they were ultimately convinced that life-life tradeoffs were actually involved-as, for example, in hostage situations in which officials are authorized to use deadly force to protect the lives of innocent people.

\footnotetext{
${ }^{31}$ See generally Arie Trouwborst, Evolution and Status of the Precautionary Principle in International Law (2002); Interpreting the Precautionary Principle (Tim O'Riordan \& James Cameron eds., 2002).

${ }^{32}$ See, e.g., Julian Morris, Defining the Precautionary Principle, in RETHINKING RISK AND THE PRECAUTIONARY PRINCIPLE (2002).

${ }^{33}$ Indeed, those skeptical of capital punishment invoked evidence to the effect that capital punishment did not deter, and argued, plausibly, that it would be a mistake to wait for definitive evidence before ceasing with a punishment that could not be shown to be reducing homicide. See Richard O. Lempert, Desert and Deterrence: An Assessment of the Moral Bases of the Case for Capital Punishment, 79 Mich. L. Rev. 1177, 1222-24 (1981). Here is a kind of precautionary principle, arguing against the most aggressive forms of punishment if the evidence suggested that they did not deter. We are arguing for a mirror-image precautionary principle when the evidence goes the other way.
} 
If capital punishment does have a strong deterrent effect, there is a crucial implication: it must be the case that capital punishment is not a wholly capricious system of punishment, pervaded by false positives. At the very least, some or many prospective murderers must believe that the system has a high degree of accuracy. The simple reason is that if capital punishment were thoroughly error-prone and seen as such, the deterrent signal of the punishment would be so diluted that it would be extremely unlikely to produce such strong and consistent empirical traces as those described above. At the limit, if capital punishment were entirely random, falling with utter arbitrariness upon innocent and guilty alike, there would be no reason for any prospective criminal to factor it into calculations about the costs and benefits of crime. In this sense, it turns out, Justice Potter Stewart's comparison of capital punishment to being struck by lightning does not hold for current systems (a point on which we will expand below). ${ }^{34}$ We do not mean to overstate this point. Of course it remains undeniable that capital punishment is sometimes imposed erroneously, and undeniable too that it is sometimes imposed arbitrarily or on invidious grounds within the set of guilty defendants. Nothing we say here is meant to suggest that states should be content with erroneous or arbitrary death sentences. But the evidence suggests that there is at least a high degree of accuracy, in the sense of avoiding false positives, in the infliction of capital punishment.

\section{Capital Punishment: Moral Foundations and Four Objections}

Assume, then, that capital punishment does save significant numbers of innocent lives. On what assumptions should that form of punishment be deemed morally unacceptable, rather than morally obligatory? Why should the deaths of those convicted of capital murder, a large fraction of whom are guilty in fact, be considered a more serious moral wrong than the deaths of a more numerous group who are certainly innocents?

We consider, and ultimately reject, several responses. Our first general contention is that opposition to capital punishment trades on a form of the distinction between acts and omissions. Whatever the general force of that distinction, its application to government systematically fails, because government is a distinctive kind of moral agent.

\footnotetext{
${ }^{34}$ Furman v. Georgia, 408 U.S. 238, 309 - 310 (1972) (Stewart, J., concurring).
} 
Our second general contention is that, apart from direct state involvement, the features that make capital punishment morally objectionable to its critics are also features of the murders that capital punishment deters. The principal difference, on the empirical assumptions we are making, is that in a legal regime without capital punishment, far more people die, and those people are innocent of any wrongdoing. No one denies that arbitrariness in the system of capital punishment is a serious problem. But even if the existing system is viewed in its worst light, it involves far less arbitrariness than does the world of homicide. Let us begin, however, with foundational issues.

\section{A. Morality and Death}

On a standard view, it is impossible to come to terms with the moral questions about capital punishment without saying something about the foundations of moral judgments. We will suggest, however, that sectarian commitments at the foundational level are for the most part irrelevant to the issues here. If it is stipulated that the evidence discussed in Part I is correct, both consequentialist and deontological accounts of morality will or should converge upon the view that capital punishment is morally obligatory. Consequentialists will do so because capital punishment minimizes killings overall. Deontologists will do so because an opposition to killing is, by itself, indeterminate in the face of life-life tradeoffs; because a legal regime with capital punishment has a strong claim to be more respectful of life's value than does a legal regime lacking capital punishment; and because modern deontologists typically subscribe to a consequentialist override or escape-hatch, one that makes otherwise impermissible actions obligatory if necessary to prevent many deaths-precisely what we are assuming is true of capital punishment. Only those few deontologists who both insist upon a strong distinction between state actions and state omissions, and who reject a consequentialist override, will believe the deterrent effect of capital punishment irrelevant in principle.

Suppose that we accept consequentialism and believe that government actions should be evaluated in terms of their effects on aggregate welfare. If so, the evidence of deterrence strongly supports a moral argument in favor of the death penalty — which, by hypothesis, seems to produce a net gain in overall welfare. Of course there are many complications here; for example, the welfare of many people might increase as a result of 
knowing that capital punishment exists, and the welfare of many other people might decrease for the same reason. A full consequentialist calculus would require a more elaborate assessment than we aim to provide here. The only point is that if capital punishment produces significantly fewer deaths on balance, there should be a strong consequentialist presumption on its behalf. To be sure, it is also possible to imagine forms of consequentialism that reject welfarism as implausibly reductionist and that see violations of rights as part of the set of consequences that must be taken into account in deciding what to do. ${ }^{35}$ For some such consequentialists, killings are, under ordinary circumstances, a violation of rights, and this point is highly relevant to any judgment about killings. But even if the point is accepted, capital punishment may be required, not prohibited, on consequentialist grounds, simply because and to the extent that it minimizes rights violations.

But imagine that we are deontologists, believing that actions by government and others should not be evaluated in consequentialist terms; how can capital punishment be morally permissible, let alone obligatory? Suppose, for example, that under ordinary circumstances, killing a human being is a wrong, and its wrongness does not depend on an inquiry into whether it produces a net increase in welfare. For many critics of capital punishment, a deontological intuition is central; evidence of deterrence is irrelevant because moral wrongdoing by the state is not justified even if it can be defended on utilitarian grounds. Compare a situation in which a state seeks to kill an innocent person, knowing that the execution will prevent a number of private killings; deontologists believe that the unjustified execution cannot be supported even if the state is secure in its knowledge of its beneficial effects. Of course it is contentious to claim that capital punishment is a moral wrong. But if it is, then significant deterrence might be entirely beside the point.

Despite all this, our claims here do not depend on accepting consequentialism or on rejecting the deontological objection to evaluating unjustified killings in consequentialist terms. The argument is instead that by itself and in the abstract, this objection is indeterminate on the moral status of capital punishment. To the extent possible, we intend to bracket the most fundamental questions and to suggest that

\footnotetext{
${ }^{35}$ Amartya Sen, Rights and Agency, 11 PHIL. \& PUB. AfF. 3, 15 - 19 (1982).
} 
whatever one's view of the foundations of morality, the objection to the death penalty is difficult to sustain under the empirical assumptions that we have traced. Taken in its most sympathetic light, a deontological objection to capital punishment is unconvincing if states that refuse to impose the death penalty produce, by that very refusal, significant numbers of additional deaths. For deontologists who emphasize life's value and object to the death penalty, the problem is acute if the refusal to impose that penalty predictably leads to significant additional murders. In a hostage situation, police officers are permitted to kill (execute) those who have taken hostages if this step is reasonably deemed necessary to save those who have been taken. If the evidence of deterrence is convincing, why is capital punishment so different in principle?

Of course we could envision a form of deontology that refuses any exercise in aggregation —one that would refuse to authorize, or compel, a violation of rights even if the violation is necessary to prevent a significantly larger number of rights violations. But most modern deontologists reject this position, instead admitting a consequentialist override to baseline deontological prohibitions. ${ }^{36}$ Although the threshold at which the consequentialist override is triggered varies with different accounts, we will suggest below that if each execution deters some eighteen murders, the override is plausibly triggered.

To distill these points: the only moral accounts that are inconsistent with our argument are those that both (1) embrace a distinction between state actions and state omissions and (2) reject a consequentialist override. To those who subscribe to this complex of views, and who consider capital punishment a violation of rights, our argument will not be convincing. In the end, however, we believe that it is difficult to sustain the set of moral assumptions that would bar capital punishment if it is the best means of preventing significant numbers of innocent deaths. Indeed, we believe that those who think that they hold those assumptions are motivated by other considerationsespecially a failure to give full weight to statistical lives—on which we focus in Part III.

\footnotetext{
${ }^{36}$ For an overview, see Larry Alexander, Deontology at the Threshold, 37 SAN DIEGo L. REV. 893, 898900 (2000).
} 


\section{B. Acts and Omissions}

A natural response to our basic concern would invoke the widespread intuition that capital punishment involves intentional state "action," while the failure to deter private murders is merely an "omission" by the state. In our view, this appealing and intuitive line of argument goes rather badly wrong. The critics of capital punishment have been led astray by uncritically applying the act-omission distinction to a regulatory setting. Their position condemns the "active" infliction of death by governments, but does not condemn the "inactive" production of death that comes from the refusal to maintain a system of capital punishment. The basic problem is that even if this selective condemnation can be justified at the level of individual behavior, it is difficult to defend for governments. ${ }^{37}$ A great deal of work has to be done to explain why "inactive," but causal, government decisions should not be part of the moral calculus. Suppose that we endorse the deontological position that it is wrong to take human lives, even if overall welfare is promoted by taking them. Why does the system of capital punishment violate that position, if the failure to impose capital punishment also takes lives?

Perhaps our argument about unjustified selectivity is blind to morally relevant factors that condemn capital punishment and that buttress the act-omission distinction in this context. There are two possible points here, one involving intention and the other involving causation. First, a government (acting through agents) that engages in capital punishment intends to take lives; it seeks to kill. A government that does not engage in capital punishment, and therefore provides less deterrence, does not intend to kill. The deaths that result are the unintended and unsought by-product of an effort to respect life. Surely — it might be said — this is a morally relevant difference. Second, a government that inflicts capital punishment ensures a simple and direct causal chain between its own behavior and the taking of human lives. When a government rejects capital punishment, the causal chain is much more complex; the taking of human lives is an indirect consequence of the government's decision, one that is mediated by the actions of a murderer. The government authorizes its agents to inflict capital punishment, but does not

\footnotetext{
${ }^{37}$ Compare debates over going to war: Some pacifists insist, correctly, that acts of war will result in the loss of life, including civilian life. But a refusal to go to war will often result in the loss of life, including civilian life.
} 
authorize private parties to murder; indeed it forbids murder. Surely that is a morally relevant difference too.

In our view, both the argument from causation and the argument from intention go wrong by overlooking the distinctive features of government as a moral agent. Whatever the general status of the act-omission distinction as a matter of moral philosophy, ${ }^{38}$ the distinction is least impressive when applied to government. ${ }^{39}$ The most fundamental point is that unlike individuals, governments always and necessarily face a choice between or among possible policies for regulating third parties. The distinction between acts and omissions may not be intelligible in this context, and even if it is, the distinction does not make a morally relevant difference. Most generally, government is in the business of creating permissions and prohibitions. When it explicitly or implicitly authorizes private action, it is not omitting to do anything, or refusing to act. ${ }^{40}$ Moreover, the distinction between authorized and unauthorized private action-for example, private killing-becomes obscure when the government formally forbids private action, but chooses a set of policy instruments that do not adequately or fully discourage it.

A system of punishments that only weakly deters homicide, relative to other feasible punishments, does not quite authorize homicide; but it is not properly characterized as an omission, and little turns on whether it can be so characterized. Suppose, for example, that government fails to characterize certain actions - say, sexual harassment-as tortuous or as violative of civil rights law, and that it therefore permits employers to harass employees as they choose, or to discharge employees for failing to submit to sexual harassment. It would be unhelpful to characterize the result as a product of governmental "inaction.” If employers are permitted to discharge employees for failing to submit to sexual harassment, it is because the law is allocating certain entitlements to employers rather than employees. Or consider the context of ordinary torts. When

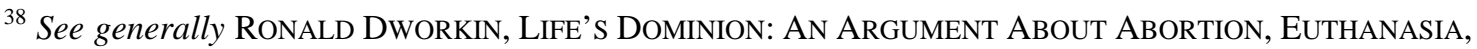
AND INDIVIDUAL FREEDOM (1993); Frances M. Kamm, Abortion and the Value of Life: A Discussion of Life’s Dominion, 95 Colum. L. Rev. 160 (1995) (reviewing Dworkin, supra); Tom Stacy, Acts, Omissions, and the Necessity of Killing Innocents, 29 Am. J. Crim. L. 481 (2002).

${ }^{39}$ Here we proceed in the spirit of Robert E. Goodin, Utilitarianism As A PuBlic Philosophy (1995), by treating government as a distinctive sort of moral agent with respect to whom many quotidian moral distinctions have little purchase. Goodin, we should note, does not address the act/omission distinction at any length, although he seems to reject it. See id. at 89.

${ }^{40}$ See Stephen Holmes and Cass R. Sunstein, The Cost of Rights (1999).
} 
homeowner B sues factory A, complaining of air pollution, a decision not to rule for B is not a form of inaction; it is the allocation to factory A of property right to pollute.

Let us apply these points, beginning with the causal version of the argument in favor of an act-omission distinction. For concreteness, suppose that government officials face a choice between two (and only two) packages of policies for reducing the murder rate. Suppose that Package A contains a range of legal instruments, such as ordinary imprisonment, imprisonment without parole (perhaps for life), post-incarceration programs to prevent recidivism, and so on. Package B contains all the same instruments plus capital punishment.

Stipulating to the validity of the evidence discussed in Part I, the crux of the issue is this: whatever the nature of the causal chain, Package A will inevitably ensure a significant increase in the number of deaths. Why should the length of the causal chain matter? In this setting, it is hard to make sense of the claim that capital punishment involves causal government "action" in some morally distinctive way. For government to opt for Package A—even in the sense of simply leaving in place previously-enacted laws that adopted Package A-is no less an "action" than it is to opt for Package B. Some criminal-justice policy or other will necessarily be in place. The only interesting or even meaningful question government ever faces is not whether to act, but what action should be taken - what mix of criminal-justice policies government ought to pursue. The policy mix that does not include capital punishment is not an "omission" or a "failure to act" in any meaningful sense. If a government chooses that mix, it is allocating a certain set of rights to both murderers and their victims; the latter are certainly given a right to be free from murder, but the right is limited by the terms of the anticipated punishment. In the extreme case, suppose that a state failed to punish certain classes of murders (say, those of African-Americans), or that it punished such murders only infrequently, or that it punished such murders with a slap on the wrist. If so, the distinction between authorizing murder, and failing to prevent it, would become thin.

The allied idea that capital punishment involves "intentional" action, whereas merely allowing (undeterred) private murders to proceed does not, misfires for parallel reasons. Consider a situation in which regulators refuse to adopt motor vehicle or drug safety regulations that would prevent significant numbers of statistical deaths; is the 
refusal acceptable because it leads to deaths that are not strictly speaking intended? The very concept of "intentional” action, and the moral relevance of intention, are both obscure when government is the pertinent moral agent. The executioner who administers the injection acts intentionally, but so does the private murderer. Proponents of this view presumably do not mean to focus narrowly on the actual individual who carries out the final action on the state's behalf. (Does it matter so much that the executioner is on the government's payroll? What if the executioner is a volunteer?) The real point is that in a regime of capital punishment the executioner acts pursuant to an explicit government policy, whereas (the idea runs) there is never a government policy to murder the particular citizens whose deaths would be deterred by capital punishment.

It is true that there is no such policy, but the moral relevance of its absence is obscure. If the point appears intuitively important, it is only because of the abstract or statistical character of the eighteen persons whose murders are deterred by each execution (a theme to which we return in Part III). The legal regime whose package of crimecontrol instruments happens not to include capital punishment does indeed embody an explicit government policy: a policy that inevitably and predictably opts for more murders over fewer. That the victims of those murders cannot be personally identified in advance does not seem a morally impressive basis for favoring the regime that makes their murders inevitable. Putting aside the intentional actions of low-level officials, the relevant policies in either regime will be set by a complex process of democratic and regulatory interaction among voters, legislators, administrators, and judges. In this largescale process of collective decisionmaking, the concept of intention becomes too attenuated to bear the moral weight often put upon $i ;^{41}$ and the regime with capital punishment does not seem importantly different, on the score of intentions, than the regime without it.

In this light, the idea that the government “authorizes” capital punishment but “forbids" private murder is too simple. Two points are important. First, of course it is true

\footnotetext{
${ }^{41}$ There is a large philosophical literature that considers whether the concept of culpability for intentional wrongdoing applies meaningfully to governments. See, e.g., CHRISTOPHER KuTZ, COMPLICITY: ETHICS AND LAW FOR A COLLECTIVE AGE (2000). There are also large literatures in jurisprudence and literary theory that consider whether the concept of intention can meaningfully be transposed from individual to collective decisionmakers. See, e.g., JeREMY WALDRON, LAW AND DisAgreEmENT (1999); Steven Knapp \& Walter Benn Michaels, Against Theory, 8 CRITICAL INQUIRY 723 (1982);Max Radin, Statutory Interpretation, 43 HARV. L. REV. 863 (1930).
} 
that the government does not authorize private killings in a retail sense, barring cases of self-defense or defense of others. At the wholesale level, however, to adopt a package of criminal-justice policies that does not include capital punishment is to ensure the murders of a large number of (as yet unidentified) victims. The government's inability to identify the victims before the fact must be morally irrelevant. Second, there is a sense in which the regime without capital punishment comes perilously close to licensing private killings, because in that regime policymakers know or should know that the prohibition on murder is supported by a weaker deterrent signal. The cash value of a prohibition lies in the scheme of punishments that enforce it; where the enforcement scheme is feeble, the prohibition is as well. On the empirical assumptions we are making, a government that eschews capital punishment rejects an effective mechanism for enforcing the baseline prohibition of murder. In the extreme case, ineffective enforcement mechanisms make the prohibition of murder begin to look like something of a sham.

So far we have argued that the act-omission distinction is conceptually obscure when applied to government, whatever its merits when applied to individuals. Even if that argument fails, however, capital punishment may still be morally obligatory for governments. The relevant acts may be morally required, or the relevant omissions morally blameworthy. We begin with the idea that declining to adopt capital punishment is a culpable omission, and then turn to the idea that adopting capital punishment is a morally obligatory act.

Suppose that there is some clear sense in which a system of capital punishment counts as relevantly "action" and that this is not the case for a refusal to impose capital punishment, which therefore counts as a kind of omission or failure to act. What is the moral importance of this distinction? Individuals, let us suppose, are prima facie obligated not to harm others, but have no obligation to assist them. Of course this view raises many puzzles, not least in the definition of the relevant categories, but let us accept it for present purposes, and ask how it applies where government is the moral agent. The government cannot easily claim that it is under no duty to assist people, at least when they are at risk of criminal violence. In administrative law, it is greatly contested whether agency inaction is subject to some special immunity from judicial review, and any such immunity turns largely on pragmatic considerations involving the limits of oversight by 
federal judges. ${ }^{42}$ Likewise, governmental failure to protect people against private violence generally does not give rise to constitutional liability, ${ }^{43}$ but this too is largely because judges have a limited capacity to enforce liability in such cases. Apart from law, there is no reason to think that omissions of this kind are properly insulated from moral criticism if significant numbers of deaths are a predictable consequence.

Alternatively, and equivalently, we can put the point within the usual language of the act-omission distinction. It is standard that an omission can count as an action where there is a "duty" to act, especially where the party subject to the duty has himself created the conditions that threaten harm. Where government is concerned, these requirements will often be fulfilled, far more often than for typical private parties. Where citizens are murdering each other, government is not a bystander, innocent or otherwise, because the decision whether to murder is made, at least in part, in light of the government's criminal-justice policies. The background rules against which citizens act to threaten the lives of others or to protect their own, including rules about and limitations on selfdefense, are themselves products of government action, including the action of the special bureaucracies that lawyers call criminal courts.

The previous points suggest that even if inflicting capital punishment is an "act" while declining to inflict it is an "omission," the omission may nonetheless be morally culpable. Conversely, the act may be morally obligatory, if large numbers are saved. Even strict deontological accounts of the impermissibility of killing typically build in a threshold exception: when the threshold is crossed, the moral agent is obliged ${ }^{44}$ to commit otherwise impermissible acts in order to save third-party lives. ${ }^{45}$ Moral theorists are typically vague as to where the threshold lies, but if each execution saves eighteen

\footnotetext{
${ }^{42}$ See Heckler v. Chaney, 470 U.S. 821 (1985).

${ }^{43}$ See DeShaney v. Winnebago County Dept. of Social Services, 489 U.S. 189 (1989).

${ }^{44}$ A more precise formulation would be "permitted or obliged," because it is unclear which moral modality holds, according to threshold deontology, once the baseline deontological prohibition is waived. Without digressing too far into moral theory, we suggest that, conditional on accepting threshold deontology, the agent is obliged (not merely permitted) to promote the best overall consequences once the threshold has been crossed. In our view it would be distinctly odd to say that a moral agent is permitted to infringe deontological constraints to save a large number of lives, but is not obliged to do so. For the related question whether general consequentialism entails an obligation to promote best consequences overall, or instead can recognize a class of supererogatory acts, see Shelly Kagan, NORMATIVE ETHICS 153-170 (1998).

${ }^{45}$ For an overview, see Larry Alexander, Deontology at the Threshold, 37 SAN DIEGO L. REV. 893, 898900 (2000).
} 
lives, then we are right in the neighborhood at which most theorists blanch at the collateral costs of deontological prohibitions. ${ }^{46}$ We offer more general remarks on deontology and its relation to the act-omission distinction below. The point here is that capital punishment may be morally obligatory even if capital punishment counts as an act while failing to impose capital punishment counts as an omission.

We have questioned both the coherence and the moral relevance of the actomission distinction as applied to capital punishment. We want to be clear, however, that in this setting, as elsewhere, rejecting the act-omission distinction only begins the analysis. For government to opt for a large highway-building project, for example, inevitably and predictably results in the deaths of a statistical set of workers who are no less real for being unidentifiable in advance. The reason the highway project is acceptable (if it is) might be either that more deaths would occur on net absent the project, or more broadly that the social benefits are higher than the costs. Likewise, capital punishment might or might not be shown to save lives, on net; might or might not turn out to be welfare-enhancing, all things considered; and might or might not turn out to be just, depending on whether we hold a welfarist conception of justice. Our point here is limited: the crucial questions that determine whether capital punishment is life-saving, welfareenhancing, or otherwise just are not questions about the difference between actions and omissions.

Consider, in this regard, the "reasonable doubt" standard of criminal law, under which it is better that some number of guilty defendants go free than that an innocent person be convicted. It is possible to imagine a defense of the reasonable doubt standard on act-omission grounds: perhaps the government "acts" when it convicts and "fails to act” when it does not convict; perhaps government errors through action are much worse than government errors through inaction. Yet this seems an unlikely description. To acquit, or to decline to convict, is government "action" whether performed by a judge or by a jury acting as the state's agents, ${ }^{47}$ under rules and procedures set by the state. Yet the reasonable doubt standard can still be straightforwardly defended on a claim that the overall social consequences of false convictions are much worse than the overall social

\footnotetext{
${ }^{46}$ See Kagan, supra note 44, at 81 (stating that a "low threshold might permit killing one to save ten.”).

${ }^{47}$ See Gary J. Simson \& Stephen P. Garvey, Knockin' On Heaven's Door: Rethinking the Role of Religion in Death Penalty Cases, 86 CoRneLL L. ReV. 1090, 1108 (2001).
} 
consequences of false acquittals. If so defended, the standard is perfectly sensible, and need not be justified by reference to an obscure distinction between acts and omissions. So too in our setting: apart from the distinction between acts and omissions, there is a reasonable question about whether capital punishment really does provide net social benefits. The relevant material for answering that question, however, is the empirical evidence discussed in Part I, rather than conceptual arguments that struggle to adapt the act-omission distinction to the state.

\section{Error, Arbitrariness, and Discrimination}

Of course there are important objections to capital punishment that do not trade on (some version of) the distinction between acts and omissions. Some of the most powerful of these objections invoke values associated with the rule of law. There are three concerns here.

1. Some innocent people are executed, and their deaths are irreversible. ${ }^{48}$ No legal system can ensure complete accuracy in criminal convictions. Even under the "no reasonable doubt” standard, errors are made. But errors are sometimes said to be intolerable when the state is depriving people of their lives, precisely because mistaken deprivations cannot be reversed.

2. The death penalty inevitably contains a degree of arbitrariness. Justice Stewart famously made the point when he wrote that receiving the death penalty is "cruel and unusual in the same way that being struck by lightning is cruel and unusual." 49 As we have seen, Justice Stewart's point is overstated for current capital punishment systems. But if any such system operates as a kind of death lottery, in which similarly situated people are not treated similarly, perhaps it is unacceptable for that reason alone.

3. Even within the set of guilty defendants, the death penalty may be administered in a way that reflects objectionable or invidious discrimination. In 2003, 42\% of the death row population was African-American and $56 \%$ was white. ${ }^{50}$ In some times

\footnotetext{
${ }^{48}$ See Liebman, supra note.

${ }^{49}$ Furman v. Georgia, 408 U.S. 238, 309 (1972) (Stewart, J., concurring).

${ }^{50}$ Bureau of Justice Statistics, Capital Punishment, 2003, available at
} 
and places, African-American defendants have been more likely to receive capital punishment than whites. More recently, those who kill white people appear to be more likely to receive capital punishment than those who kill AfricanAmericans. ${ }^{51}$ The system of capital punishment might reflect a form of institutional racism; even if not, the system might simply operate against the background of racial injustice, which ensures intolerable inequalities in the imposition of death. In any event, capital defendants who are poor, or otherwise unlikely to have good lawyers, are far more likely to face the death penalty as a result.

Some people believe that even if capital punishment could be morally acceptable if it were fairly administered, the inevitability of unfair administration means that we must eliminate it. These arguments point to strong reasons for reforming the existing system to increase accuracy and decrease arbitrariness. But the arguments do not succeed as objections to capital punishment as such. Once the act-omission distinction is no longer central, it becomes clear that the standard moral objections to capital punishment apply even more powerfully to the murders that capital punishment prevents. Those murders also cause irreversible deaths: the deaths of the victims of murder. Private murders are also often highly arbitrary, involving selectivity on any number of morally irrelevant or objectionable grounds. African-Americans, for example, are far more likely than other groups to be the victims of murder. In 2003, 48\% of murder victims were white and $48 \%$ were African-American-meaning that the racial disparity in the probability of becoming a murder victim is even greater than the racial disparity in the

http://www.ojp.usdoj.gov/bjs/pub/pdf/cp03.pdf.

${ }^{51}$ For a well-known discussion, see Randall Kennedy, McCleskey v. Kemp: Race, Capital Punishment, and the Supreme Court, 101 Harv L Rev 1388 (1988). For recent evidence, see John Blume, Theodore Eisenberg, \& Martin T. Wells, Explaining Death Row's Population and Racial Composition, 1 J. Emp. L. Stud. 165 (2004). On the basis of their data, it is possible to estimate the rate at which death sentences are issued (per 1000 murders):

\begin{tabular}{|l|l|}
\hline Black on black & 6.7 \\
\hline Black on white & 62.2 \\
\hline White on white & 28.4 \\
\hline White on black & 18.6 \\
\hline
\end{tabular}


probability of ending up on death row. ${ }^{52}$ An important corollary is that the benefits of capital punishment, to the extent that it operates as a powerful deterrent of murder, are likely to flow disproportionately to African-Americans. ${ }^{53}$

To be sure, this effect will be attenuated if death sentences are imposed less frequently on those who murder African-Americans. In the most pessimistic projection, capital punishment is likely to be disproportionately inflicted on African-Americans, and because that punishment is most likely to be imposed when whites have been killed, the resulting savings are likely to go largely to whites. On this view, the "life-life tradeoffs" may turn out, all too often, to be "African-American life-white life tradeoffs." Perhaps it is unclear how to make that tradeoff, even if it involves larger numbers, and innocence, on one side of the ledger. But even on the current numbers, this projection is unrealistic. Most murder is intraracial, not interracial. ${ }^{54}$ Because African-Americans are disproportionately the victims of homicide, and because their murderers are disproportionately African-American, they have a great deal to gain from capital punishment—-very plausibly more, on balance, than white people do. ${ }^{55}$ In any event, the

52 See Federal Bureau of Investigation, Crime in the United States 2003, at Table 2.3 (2003), available at http://www.fbi.gov/ucr/03cius.htm.

${ }^{53}$ See Randall Kennedy, McCleskey v. Kemp: Race, Capital Punishment, and the Supreme Court, supra note.

${ }^{54}$ See id. (tabulating murders as follows:

White murdering white: 3,017

African-American murdering African-American: 2,864

White murdering African-American: 226

African-American murdering white: 501

${ }^{55}$ This judgment is supported by Blume et al., giving relevant figures for the demographics of murder: Table A1: National Estimate of Death Row Composition Using Seven States' Data

\begin{tabular}{lcccc}
\hline & $\begin{array}{c}\text { Black Offender- } \\
\text { Black Victin }\end{array}$ & $\begin{array}{c}\text { Black Offender- } \\
\text { White Victim }\end{array}$ & $\begin{array}{c}\text { White Offender- } \\
\text { White Victim }\end{array}$ & $\begin{array}{c}\text { White Offender- } \\
\text { Blad Victim }\end{array}$ \\
\hline $\begin{array}{c}\text { National known } \\
\text { murderers 1976-98 }\end{array}$ & 113,649 & 19,987 & 118,488 & 7,048 \\
$\begin{array}{c}\text { Estimated number } \\
\text { of death sentences }\end{array}$ & 767 & 1,243 & 3,368 & 131 \\
$\begin{array}{c}\text { Estimated national } \\
\text { percent of death row }\end{array}$ & $14.6 \%$ & $23.8 \%$ & $55.0 \%$ & $2.5 \%$ \\
\hline
\end{tabular}

NOTE: Using seven states with known race of offender-race of victim data, the table estimates the percentage of death row consisting of the indicated racial combinations for the 31 states in this study. The percentages in the third row do not total 100 because we limit our national murder sample to those cases with whites and blacks as offenders and victims.

Because cases of white victims and African-American offenders are such a small percentage of the total number of murders, the pessimistic scenario discussed in text is not a plausible reading of the numbers. 
more natural response to existing racial disparities is to lower them, rather than to eliminate the penalty altogether.

For the rule of law questions, as for all others, the core problem of capital punishment is that it presents a risk-risk tradeoff, or a life-life tradeoff. To say the least, it is extremely desirable to prevent arbitrary or irreversible deaths, but this consideration is on both sides of the ledger. The relevant analogy is not, say, to a policy that uses racial classifications to increase security or national wealth. The closer analogy would be one that uses racial classifications in order to minimize the overall use of racial classifications, or to hasten the day when racial classifications are no longer useful. ${ }^{56} \mathrm{~A}$ still closer analogy would be a policy that increases certain risks but that in the process decreases other risks of greater magnitude. Whatever the merits of such tradeoffs across different settings, a one-sided complaint about a harm or loss that is on both sides of the ledger is not a sufficient objection to a policy of this sort.

On this view, the crucial point is that a legal regime with capital punishment predictably produces far fewer arbitrary and irreversible deaths than a regime without capital punishment. In a sensible regime of capital punishment, legal rules, enforced by administrative, judicial and citizen oversight, attempt to reduce arbitrariness and error up to the point where further reductions would inflict unacceptable harms. ${ }^{57}$ Where killing is carried out by private parties, however, there are no such institutions for keeping arbitrariness in check. Most striking is the sheer size of the opportunity cost of foregone capital punishment. Stipulate that for every foregone execution (conducted under procedural safeguards), the cost is on average, some eighteen arbitrary and irreversible murders - as some of the evidence in Part I suggests. Suppose, for example, that five hundred additional death row inmates were executed in the next year. ${ }^{58}$ Unless the

\footnotetext{
${ }^{56}$ See, e.g., Regents of University of Calf. v. Bakke, 438 U.S. 265, 407 (1978) (Blackmun, J., concurring in the judgment in part and dissenting) ("In order to get beyond racism, we must first take account of race.”); Grutter v. Bollinger, 539 U.S. 306, 341 - 43 (2003) (“We expect that 25 years from now, the use of racial preferences will no longer be necessary to further the interest approved today.”); United Steelworkers of Am., AFL-CIO v. Weber, 444 U.S. 193, 208 (1979) (upholding voluntary private affirmative action plans "designed to break down old patterns of racial segregation and hierarchy).

57 This formulation is meant as a placeholder for the appropriate degree of reduction. We bracket the relevant questions here, beyond noting that the courts typically use a calculus of decision costs and error costs to assess the marginal value of additional procedures. See Matthews v. Eldridge, 424 U.S. 319 (1976).

58 The death row population is now over 3000. See BurEau of Justice Statistics, CAPital PunishmENT, 2003, at 1 (2004), available at http://www.ojp.usdoj.gov/bjs/pub/pdf/cp03.pdf.
} 
marginal deterrent benefit of each additional execution diminishes very rapidly, the result would be to save thousands of innocent people-in all probability, far more people than were killed in the terrorist attacks of September 11, 2001. The people whose lives are lost, and whose deaths could be averted, are killed arbitrarily and without fair process. In short, rule-of-law criticisms of capital punishment either smuggle in the distinction between acts and omissions, or else overlook the fact that the same objections apply even more powerfully to the utterly arbitrary killings that capital punishment prevents.

\section{Preferable Alternatives and the Principle of Strict Scrutiny}

Some critics of the death penalty believe that there are other, better ways of deterring murder, and states ought to use those ways instead. ${ }^{59}$ Deterrence might occur through superior law enforcement efforts. Or it might occur through taking steps to reduce people's incentives to engage in violent crime; education, job training, and other steps toward poverty reduction are preferred remedies here. On this view, capital punishment reduces the pressure to take better and less barbaric steps to control homicide.

Here there is an analogy, though an imperfect one, to the principle of "strict scrutiny” found in many areas of constitutional law. Although constitutional law often permits government to act in ways that burden important rights, government must typically show that no alternative policy would promote the same goals with less burden on the affected right. ${ }^{60}$ The analogy is imperfect because strict scrutiny in the courts is often "strict in theory but fatal in fact,"61 with courts often barring government from satisfying strict scrutiny by reference to arguments that are routinely acceptable in the process of policy evaluation. Here we use "strict scrutiny" as a shorthand for the argument that capital punishment is justified only if, and when, a rational policy evaluation would show that no alternative policies could do as much to reduce murder

\footnotetext{
59 See Hugo Bedau, An Abolitionist's Survey of the Death Penalty in America Today, in DEBATING THE DeAth Penalty 15 (Hugo Bedau \& Paul Cassell eds., 2004).

${ }^{60}$ See, e.g., Grutter v. Bollinger, 539 U.S. 306, 326 - 327 (2003).

${ }^{61}$ Gerald Gunther, The Supreme Court, 1971 Term--Foreword: In Search of Evolving Doctrine on a Changing Court: A Model for a Newer Equal Protection, 86 HARV. L. REV. 1, 8 (1972).
} 
rates. The Supreme Court has not accepted this idea as a matter of constitutional law. ${ }^{62}$ But perhaps it should be accepted as a normative matter.

Here is the simplest response. On the basis of the evidence that we are assuming to be true, a plausible inference is that whatever steps states take to reduce homicide, capital punishment will provide further deterrence. Whatever states do, some level of homicide is inevitable; so long as liberty is respected, a significant number of murders will continue to occur in every state. If states undertook the steps that are recommended as less restrictive alternatives - and they surely should undertake some of them-then capital punishment would still reduce that level from what it would otherwise be. In other words, a key assumption of the strict-scrutiny view is that the alternative policies are substitutes for capital punishment. Yet they would likely turn out to be complements instead. Many steps can be simultaneously taken to reduce violent crime, and the criminal justice system is only one of those steps.

Moreover, the strict-scrutiny position rests upon an excessively simple view of legal policymaking. The first question is, always, what policies lie in the feasible set. Political constraints will rule out some policies that might be even better, from the standpoint of deterring murders, than is capital punishment. Switching to a Swedish-style welfare state might (or might not) reduce crime dramatically, but we will never know because we will never try it. So too, increasing job-training funds by several orders of magnitude might result in many fewer murders, but such policies are simply not on the cards. Capital punishment, by contrast, is very much a live policy option, even in many states that do not currently use it. ${ }^{63}$ Perhaps the apparent political constraints are partially endogenous; perhaps capital punishment reduces the political incentive to adopt other strategies, and if this were so, the argument for capital punishment would surely be weakened. But there is little reason to believe that if capital punishment were abolished, there would be significantly larger efforts to reduce violent crime through education and training programs. We cannot rule out the possibility that abolition would result in a

\footnotetext{
${ }^{62}$ See, e.g., Gregg v. Georgia, 428 U.S. 153, 175 (1976).

${ }^{63}$ See, e.g., Rick Klein, Science Key in Building Case for Death Law, Boston GLOBE, Sept. 30, 2003, at B1 (reporting that a majority of Massachusetts residents support the death penalty and that the state's Governor is developing a capital punishment proposal).
} 
better mix of measures, all things considered. But if the death penalty has the deterrent effect suggested by the recent literature, then this would be a surprising conclusion.

In general, there is no reason to say that capital punishment must be prohibited unless and until all available alternatives have been tried and proven inferior. No sensible principle of policymaking bars regulators from adopting a clearly desirable practice, unless and until they show that all other potential projects are inferior. Such a view overlooks the opportunity cost of searching through the policy space and exhausting the available alternatives. In the setting of capital punishment, the alternatives might be tried and fail; even if they succeed, approaches based on education and social-welfare provision will often have a longer lag time before they bear fruit. In either case, while the policy experiments are ongoing, a large number of murders will go undeterred. The hard question is what the interim policies should be while regulators search for optimal arrangements, and it begs the question to say that the interim policy must be a regime without capital punishment. Why should that be so, if there is powerful evidence that instituting capital punishment today will save many lives starting tomorrow?

As the last point shows, the strict-scrutiny idea goes wrong in the same sort of way that the earlier arguments go wrong: by overlooking that the regime without capital punishment itself inflicts even larger net harms-harms to the very same values that animate opposition to capital punishment. This is a version of the act-omission mistake. Given that capital punishment saves many more innocent lives than it takes, the strictscrutiny argument has the default position backwards. Criminal-justice policy would do well to adopt capital punishment while the search for regulatory alternatives proceeds; it is the alternatives that should be strictly scrutinized, to be rejected unless and until they prove themselves superior.

\section{E. Slippery Slopes}

Our argument might seem to have serious slippery slope problems. Suppose, for example, that the best way to deter heinous crimes is to torture perpetrators. Suppose that if torture were undertaken, there would be a significant reduction in the number of such crimes. The logic of our hypothesis is that torture would be morally obligatory on certain factual assumptions. 
We accept this claim about what our hypothesis entails. To make the case as simple as possible, suppose that some criminals torture their victims, and that if such criminals were themselves tortured, the incidence of torture would decrease substantially. Suppose, that is, a ban on (state) torture ensures that (private) torture will occur far more than it otherwise would. In our view, the ban on state torture reflects a use of the actomission distinction in a context in which the distinction is not easy to defend. If, for example, state torture of a torturer would prevent eighteen acts of torture-of, say, children - the argument for banning state torture would be greatly weakened.

None of this means that a ban on state torture is indefensible. ${ }^{64}$ Here as always, rejecting the act-omission distinction says nothing, by itself, about what policies are best from any point of view. State practices of torture might actually increase torture, rather than diminish it, perhaps by weakening the social prohibition on torture. This is an empirical issue, and no evidence, so far as we are aware, either undermines or confirms it. Hence state torture might be self-defeating, if its goal is to reduce private torture. In any case a ban on torture might, or might not, have a rule-consequentialist defense, if the benefits of state torture are low, if its costs, prominently including the risks of abuse, are high, and if front-line decisionmakers cannot be trusted to sort good instances from bad instances. Everything depends on what the facts turn out to be.

The last point is crucial. Because arguments about policies such as capital punishment and torture are hostage to what the facts turn out to show in particular domains, slippery-slope arguments are disabled; instead of a slope, there is just a series of discrete policy problems. Support for capital punishment need not, by analogical reasoning or otherwise, commit policymakers to support for public floggings or punitive mutilation or other horrors. Nor is there any obvious mechanism that would push policymakers or citizens to adopt those other practices once they have adopted capital punishment. ${ }^{65}$ Not only is there no slope, there is no a priori reason to believe the ground slippery.

\footnotetext{
${ }^{64}$ For relevant considerations, see Eric A. Posner \& Adrian Vermeule, Should Coercive Interrogation Be Legal? (draft on file with the authors).

${ }^{65}$ For criticism of slippery-slope arguments that lack a specific mechanism, see Frederick Schauer, Slippery Slopes, 99 HARV. L. REV. 361 (1985); Eugene Volokh, The Mechanisms of the Slippery Slope, 116 HARV. L. REV. 1026 (2003).
} 
Perhaps the torture example fails to get to the heart of what is most objectionable in our argument. Return to a problem raised above and focus on the following question: "Suppose that holding a show trial to frame and convict one innocent person of murder would deter eighteen real murders. Wouldn't you be obliged to defend that, crazy as it is?” On one view, the question is fair. It is possible to imagine a finding that a show trial of this sort would deter murders, so that the failure to hold show trials is, in effect, condemning large numbers of people to unjustified deaths. On utilitarian grounds, the show trials might be permissible or even mandatory. On deontological grounds, the answer is at first clear: The state cannot take the lives of innocent people. But if our argument is correct, the deontological argument might not be so clear after all: Might not the failure to conduct show trials be a way of taking the lives of innocent people, too?

The problem with slippery slope questions of this kind is that they often obscure more than they clarify. ${ }^{66}$ First, as Rawls pointed out long ago, the systemic effects of a government policy that allowed sham convictions of the innocent, including debilitating uncertainty for other innocents, would themselves have to be folded into the overall assessment. ${ }^{67}$ Only a conspiracy to keep the policy secret would prevent the unraveling. No such conspiracy is likely to succeed. Put differently, such a policy would violate the publicity constraint emphasized by Rawls and others. It could not be defended publicly and still accomplish its central goal. ${ }^{68}$ The publicity constraint is a principle of political morality that can be given both deontological and consequentialist justifications, ${ }^{69}$ so moral theorists of many stripes could reject this sort of hypothetical.

Second, it is not clear how policymakers could have reliable evidence about the deterrent effects of show trials, torture or other disturbing practices without first experimenting on hapless victims; and the necessary experimentation might well be impermissible on moral grounds ex ante, even if the policies themselves would be

\footnotetext{
${ }^{66}$ Note that a widely held view, which we do not mean to endorse, insists that there is a kind of moral floor for the infliction of severe punishment, a floor that rules out punishment of the innocent, or punishment that is grossly excessive in comparison to the crime, but that permits the death penalty, if the evidence supports it, after people have been convicted, under stringent standards, of committing especially egregious murders.. Of course any floor will be controversial, and the most adamant opponents of capital punishment might believe that it is below the floor by its very nature.

${ }^{67}$ See John Rawls, Two Concepts of Rules, 67 PhiLOSophiCAl Review 3-32 (1955).

${ }^{68}$ On the publicity condition, see John Rawls, A Theory of Justice (1971).

${ }^{69}$ For an overview of issues, see David Luban, The Publicity Principle, in THE THEORY OF INSTITUTIONAL DESIGN 154 (Robert Goodin ed. 1996).
} 
permissible given certain experimental findings ex post. Capital punishment, however, is already the status quo in most states, and policymakers already have many decades' worth of reliable data about its deterrent effects.

Finally, and most fundamentally, we doubt that the intuitions that drive extreme hypotheticals of this sort have moral significance in any event. Of course it is prima facie objectionable, worse than outrageous, if the state proposes to kill people whom it knows to be innocent. The widely held moral and legal norm against executions of innocent people is certainly an individual and social good, whatever one's views about the foundations of morality. But suppose that a situation arises in which execution of an innocent person really is the only way to save eighteen, or eighty, or eighteen hundred innocent people. There is no reason to think that intuitions about the extreme cases are reliable trackers of moral truth, or to assume that such intuitions have any privileged connection to what a considered moral theory would permit or require; consider the obvious tension between any such intuitions and the accepted practice of killing hostagetakers. We offer more remarks on the moral status of particular intuitions below, and in Part III.

\section{F. Deontology and Consequentialism Again}

What is the relationship between the foregoing argument, particularly our rejection of the act-omission distinction as applied to government's policy choices, and standard debates about deontological and consequentialist approaches in moral theory? We do not think this is a crucial analytic lens for the questions we address. ${ }^{70}$ As we have emphasized, our argument does not challenge deontological claims as such, except insofar as they apply the act-omission distinction to government and reject any consequentialist override of deontological injunctions. The simple injunction "thou shalt not kill” is too general to cut between the relevant options at the lower level of policy choice. If capital punishment strongly deters killings, and if the government that eschews capital punishment can fairly be charged with those killings, then the government's only

\footnotetext{
${ }^{70}$ For a recent argument that most or all substantive moral positions can be formulated at will in either deontological or consequentialist terms, see Campbell Brown, Consequentialise This (2004), at http://socpol.anu.edu.au/ cbrown/papers/ConsThis.pdf.
} 
choices are to kill more or to kill fewer; the deontological injunction might then be interpreted to require rather than to forbid capital punishment.

To be sure, some opponents of capital punishment tend to build the act-omission distinction directly into the deontological injunction itself. "Thou shalt not kill” might be interpreted just to mean that the state and its agents shall not themselves kill. Moreover, opponents sometimes assume away the problem of consequentialist overrides. But as we have seen, both the act-omission distinction, and the idea that deontological injunctions are absolute, are highly contentious assumptions; they require independent arguments on their behalf. In many cases, no such argument is offered; all that is typically offered is an intuition that the state must not kill, period.

We do not believe that, upon reflection, the intuition can be defended, nor do we think that case-specific intuitions should be morally dispositive. In part this is because of familiar arguments in moral theory that commitments to generalizable moral principles should trump intuitions in particular cases. ${ }^{71}$ In part it is because the reliability of such intuitions is highly suspect. Recent research in cognitive psychology, which we discuss in Part III, suggests that the intuitions underpinning the act-omission distinction may represent cognitive errors, without any moral relevance or larger importance. The only point we emphasize here is that, in light of the recent evidence that capital punishment powerfully deters killings, an opposition to killing is most naturally understood to support capital punishment rather than to undercut it. Opponents of capital punishment who build the act-omission distinction directly into an absolutist deontological injunction, by stating a position against state killing with no consequentialist override, face the prospect that their position will ultimately come to rest upon little more than an inarticulate intuition, a conclusion masquerading as an argument.

Overall, the crucial question is what the facts show, a point to which we return in Part IV. Perhaps capital punishment might best be restricted to certain classes of offenders or offenses, or even to certain geographic regions; different polities might, in their different factual circumstances, each do well by adopting or rejecting capital punishment as appropriate. It might even turn out that the system of capital punishment is so riddled with errors and arbitrariness that it would be unwise and unjust to adopt it,

\footnotetext{
${ }^{71}$ See generally R.M. HARE, Moral ThinKInG: Its LeVels, Methods, AND PoINT (1981).
} 
simply because it is a hopelessly defective tool of criminal justice. Although we doubt very much that this is so, for the reasons given in Part I, it could be so, and a belief that it is so would supply a very respectable reason for opposing capital punishment. What does not supply such a reason is an indeterminate and unprocessed intuition that the state should not "kill."

None of this is to suggest that intuitionism is the only possible basis for opposing capital punishment; of course it is not. Perhaps the death penalty is opposed (as it is sometimes endorsed) on expressivist grounds; perhaps the social meanings of capital punishment are what drive opponents as well as advocates. ${ }^{72}$ But if the evidence outlined here is correct, expressivist opposition is not so easy to sustain. A failure to protect workers against severe occupational risks is objectionable on expressive grounds because it reflects contempt for the safety of workers. ${ }^{73} \mathrm{~A}$ failure to take steps that would prevent significant numbers of murders is itself expressively objectionable, on parallel grounds.

There is a final point, involving democracy itself. On one view, government's central obligation is to follow the public will, assuming that it has been properly focused and channeled through processes of public deliberation. ${ }^{74}$ If the public opposes capital punishment, and insist on an act-omission distinction, then officials should oppose it too, unless, perhaps, opposition can be shown to be ill-informed or to have failed the minimal requirements of political deliberation. And on this view, public support for capital punishment would be presumptively binding as well. We do not mean to say anything contentious about democratic legitimacy here. Both citizens and representatives must ask themselves about what morality requires. If a life-life tradeoff is involved, the moral question is inevitably affected. And if capital punishment saves large numbers of innocent lives, then participants in democracies are obliged to take note of that fact.

\section{Cognition and Capital Punishment}

Those who object to capital punishment, and who are not much moved by evidence of deterrence, believe that they are operating in accordance with a freestanding moral principle. They will not be enthusiastic about the suggestion that their moral

\footnotetext{
${ }^{72}$ See Dan M. Kahan, The Secret Ambition of Deterrence, 113 Harv L Rev 413 (1999).

${ }^{73}$ See Elizabeth Anderson, Value In Ethics and Economics (1993).

${ }^{74}$ See William Bessette, The Mild Voice of Reason (1993).
} 
judgments are instead a product of some kind of cognitive error. But in the regulatory domain as a whole, it has become standard to say that cognitive processes contribute to large mistakes, at least on questions of fact. ${ }^{75}$ For risk regulation, people do seem to focus on a subset of the harms at stake, in a way that produces both excessive and insufficient reactions to environmental problems. ${ }^{76}$ More generally, a form of "tradeoff neglect" pervades regulatory policy ${ }^{77}$; and it is easy to imagine that the moral domain has its own kinds of tradeoff neglect. For example, it is common, in the environmental domain, to focus on the risks associated with some kind of environmental degradation, but to neglect the risks associated with environmental regulation; and those who focus on the costs of regulation often neglect the risks of inaction. ${ }^{78}$

In a related vein, a great deal of recent work has emphasized the possibility that heuristics and biases can be found in the moral arena, ensuring that deeply felt moral intuitions are a result of errors and confusions. ${ }^{79}$ This is a possibility and no more. Certainly we cannot demonstrate that opposition to capital punishment is rooted in selective attention or an identifiable heuristic. But return to the hostage situation to which we have referred: Police officers are permitted to kill those who have taken hostages, at least if the killing is reasonably believed to be necessary to save human lives. If capital punishment is deemed differently, it might be because the lives to be saved are merely statistical, as compared with the lives of hostages, which are entirely vivid. More generally, consider two points, the first involving salience, the second involving the foundations of the act-omission distinction.

\footnotetext{
${ }^{75}$ Roger G. Noll \& James E. Krier, Some Implications of Cognitive Psychology for Risk Regulation, 19 J. LEGAL STUD. 747, 777 (1990).

${ }^{76}$ This is the theme of Howard Margolis, Dealing With Risk: Why the Public and the Experts Disagree on Environmental Issues (1996).

${ }^{77}$ Id.

${ }^{78}$ Id.

${ }^{79}$ See, e.g., Jonathan Baron, Heuristics and Biases in Equity Judgments: A Utilitarian Approach, in Psychological Perspectives on Justice (Barbara A. Mellers \& Jonathat Baron eds., 1993); Jonathan Haidt, The Emotional Dog and Its Rational Tail: A Social Intuitionist Approach to Moral Judgment, 108 Psychol. ReV. 814 (2001); Cass R. Sunstein, Moral Heuristics (2d John M. Olin L. \& Econ. Working Paper No. 180, 2003).
} 


\section{A. Salience}

It is obvious that people's reactions to factual and moral questions are much affected by vividness or salience. ${ }^{80}$ If an event, such as a terrorist attack, seems salient, people will think it is more likely to occur. And if an event is salient, people may not pay much attention to less salient possibilities, such as the risk that a response to a terrorist attack will cause a significant number of deaths of its own. When people neglect tradeoffs, it is often because one aspect of the situation is highly visible, or "on screen," while other aspects are less visible or perhaps invisible.

Consider in this regard the life-life tradeoffs involved with capital punishment. Those subject to capital punishment are real human beings, with their own backgrounds and narratives. Some of them have been subject to multiple forms of unfairness, in the legal process and elsewhere. At least some were wrongly convicted. By contrast, those whose lives are or might be saved by virtue of capital punishment are mere "statistical people." 81 They are both nameless and faceless, and their deaths are far less likely to count in moral deliberations. It is, for this reason, perhaps, that the advocates of capital punishment often focus on the heinousness of the (salient) offender, while the abolitionists focus on his or her humanity. We suspect that the discussion would take a different form if the victims of a regime lacking capital punishment were salient too ${ }^{82}$; and the example of police behavior in hostage situations supports the suspicion. None of this establishes the claim that the death penalty is morally required if it saves far more lives than it ends. But it does raise the possibility that moral intuitions, for many people, are a product of the salience of one set of deaths and the invisibility or speculativeness of another.

\footnotetext{
${ }^{80}$ See Scott Plous, The Psychology of Judgment And Decision MaKing 125-26, $178-80$ (1993) (discussing the salience heuristic and the closely related heuristics of vividness and availability). Cf. Robert M. Reyes, William C. Thompson \& Gordon H. Bower, Judgmental Biases Resulting from Differing Availabilities of Arguments, 39 J. PERSONALITY \& Soc. PSYCHOL. 2, 5-12 (1980) (demonstrating that vivid, concrete information exerts greater influence on mock jury deliberations than abstract, pallid information).

${ }^{81}$ See Lisa Heinzerling, The Rights of Statistical People, 24 HARV. ENV. L. REV. 189, 189 (2000).

${ }^{82}$ Cf. PhiLIP K. DiCK, ThE MiNORITY REPORT (2002).
} 


\section{B. Acts, Omissions, and Brains}

Outside of the domain of government, we have not questioned the act-omission distinction here. But in some settings, it may be worth considering the possibility that the act-omission distinction operates as a heuristic for a more complex and difficult assessment of the moral issues at stake. ${ }^{83}$ Consider in this regard the dispute over two well-known problems in moral philosophy. ${ }^{84}$ These problems do not involve the actomission distinction, but they implicate closely related concerns. We suggest that people's asymmetrical reactions to the two problems say a great deal about the operation of the act-omission distinction.

The first, called the trolley problem, asks people to suppose that a runaway trolley is headed for five people, who will be killed if the trolley continues on its current course. The question is whether you would throw a switch that would move the trolley onto another set of tracks, killing one person rather than five. Most people would throw the switch. The second, called the footbridge problem, is the same as that just given, but with one difference: the only way to save the five is to throw a stranger, now on a footbridge that spans the tracks, into the path of the trolley, killing that stranger but preventing the trolley from reaching the others. Most people will not kill the stranger. What is the difference between the two cases, if any? A great deal of philosophical work has been done on this question, much of it trying to suggest that our firm intuitions can indeed be defended in principle. ${ }^{85}$

Without engaging these arguments, consider a suggestive experiment designed to see how the human brain responds to the two problems. ${ }^{86}$ The authors do not attempt to answer the moral questions in principle, but they find "that there are systematic variations in the engagement of emotions in moral judgment, ${ }^{, 87}$ and that brain areas associated with emotion are far more active in contemplating the footbridge problem than in contemplating the trolley problem. An implication of the authors' finding is that human

\footnotetext{
${ }^{83}$ The argument is ventured in JonAthan BARON, Judgment Misguided: InTUITION AND ERRor IN Public DECISION MAKING (1998).

${ }^{84}$ See Judith Jarvis ThOMson, Rights, Restitution, AND Risk: EsSAys in MORAl ThEORY 94-116 (1986).

${ }^{85} \mathrm{Id}$.

${ }^{86}$ Joshua Green et al., An fMRI Investigation of Emotional Engagement in Moral Judgment, 293 SCIENCE 2105 (2001).

${ }^{87}$ Id. at 2107.
} 
brains are hard-wired to distinguish between bringing about a death "up close and personal" and doing so at a distance. ${ }^{88}$

Of course this experiment is far from decisive; emotions and cognition are not easily separable, ${ }^{89}$ and there may be good moral reasons why certain brain areas are activated by one problem and not by the other. Perhaps the brain is closely attuned to morally relevant differences. But consider the case of fear, where an identifiable physical region of the brain makes helpfully immediate but not entirely reliable judgments. ${ }^{90}$ So too, very plausibly, in the context of morality. ${ }^{91}$

For capital punishment, the implication is straightforward. For many people, the prospect of lethal executions is akin to the prospect of throwing the stranger in the footbridge problem; we expect that the relevant part of the brain would light up for most people who sincerely imagine themselves in the position of executioner. But for almost everyone, no such lights would be found after learning that the consequence of abolishing capital punishment was to ensure somewhere between eight and twenty-eight statistical deaths for each foregone execution. No unambiguous moral lesson follows from an understanding of the operation of the human brain. But it is perhaps illuminating if moral judgments are caused by rapid intuitions that do not involve a great deal of cognitive work, and that have no obvious connection to the morally relevant features of the situation.

\section{A Famous Argument That Might Be Taken as a Counterargument}

Our general claims might be thought to run up against Bernard Williams' wellknown critique of utilitarianism, rooted largely in a story about an unfortunate tourist named Jim. ${ }^{92}$ In Williams' tale. Jim is a tourist in a small town in South America. He notices that twenty Indians are about to be shot. The leader of the shooters gives Jim a chance to save all but one of the Indians, for a price: Jim has to shoot one of them. Williams believes that for utilitarians, the moral answer is clear: Jim should shoot. But in

\footnotetext{
${ }^{88} \mathrm{Id}$.

${ }^{89}$ See Martha C. Nussbaum, Upheavals of Thought: The InTELligenCE OF EMOTIONS (2001).

${ }^{90}$ See Joseph E. LeDoux \& Jeff Muller, Emotional Memory and Psychopathology, 352 Philosophical Transactions: Biological Sciences 1719, 1719 (1997).

${ }^{91}$ Joshua Green \& Jonathan Haidt, How (And Where) Does Moral Judgment Work?, 6 Trends in Cognitive Sciences 517, 522 - 23 (2002).

${ }^{92}$ See J. J. C. SMART \& BERNARD Williams, Utilitarianism: For AND AGAinst 98-99 (1973).
} 
his view, it is not clear that this is what morality requires. In Williams' words, utilitarianism "cuts out a kind of consideration which for some others makes a difference to what they feel about such cases: a consideration involving the idea, as we might first and very simply put it, that each of us is especially responsible for what he does, rather than for what other people do."93 Williams asks: "how can a man, as a utilitarian agent, come to regard as one satisfaction among others, and a dispensable one, a project or attitude round which he has built his life, just because someone else's projects have so structured the causal scene that that is how the utilitarian sum come out?"94

We believe that an intuition akin to Williams' helps to explain opposition to capital punishment even in the face of evidence of the sort that we have outlined. But there are three responses. Most modestly: Capital punishment, on the evidence given here, more closely resembles a hostage situation than Jim's case. Recall that police officers are permitted, even expected, to use deadly force against those who have taken hostages if that is the only way to save innocent people. Those who are subject to capital punishment are (almost always) egregious wrongdoers, not innocents. Somewhat less modestly: An understanding of the attitudes around which people have built their lives might constrain people, but such an understanding does not constrain states, at least not in the same way. If Jim is a police officer, asked to save twenty hostages, he might well be morally obliged to shoot one of them if that is the only way to save the other nineteen. If Jim is the head of state, asked to engage in military intervention to prevent a mass slaughter (say, in Rwanda), it is not so clear that he should refuse even if he knows that military intervention will also result in innocent deaths at the hands of his own military. At the very least, the moral question cannot be answered, at the level of the state, by insisting "that each of us is especially responsible for what he does, rather than for what other people do.” Less modestly still: Williams ' own arguments seem to us to rely on question-begging claims about causation, and about what counts as intentional action. He is right to say that we are particularly responsible for what we do; but in Jim's case, how does that precept cash out, exactly? Granted that Jim faces bad choices, through no fault

\footnotetext{
${ }^{93}$ Id. at 99.

${ }^{94} \mathrm{Id}$ at 116 .
} 
of his own; but can Jim disclaim responsibility for the unnecessary death of nineteen people?

IV. Implications and Future Problems

Here we expand upon the implications of our approach and highlight some remaining puzzles, not with a view to resolving all issues, but with a view to indicating the contours of existing puzzles and some possible directions for future research. We also emphasize that our argument is limited to the setting of life-life tradeoffs: cases in which capital punishment is used to deter killing, rather than other offenses.

\section{A. Threshold Effects (?) and Regional Variation}

The statistic that each execution saves eighteen lives, on average, is an aggregated statistic based on national-level data-something like a national average. Averages can be misleading, of course, and a look at regional variation suggests a potentially complicated picture. The most recent work suggests that states fall into three sets: a set of states in which capital punishment deters very strongly, a set in which it has no deterrent effect at all, and even a set in which capital punishment has perverse effects, slightly raising murder rates. The pronounced deterrent effect at the level of the national average occurs because, where capital punishment does deter, it deters powerfully. As we mentioned in Part I, Joanna Shepherd suggests there is a "threshold effect" at work here: in states that execute very few, capital punishment either has no effect or even backfires, perhaps because (Shepherd conjectures) a "brutalization effect" operates; while states that execute a larger number see large deterrent effects. Whatever the validity of the particular mechanisms Shepherd proposes, it seems plausible that capital punishment deters strongly in one set of states and has little effect in others. If this is correct, does it undermine our thesis?

The simple answer is no, not at all, because we hold no brief to promote capital punishment everywhere, at all times and places. Where capital punishment is a powerful deterrent, we have suggested that states may well be morally obligated to adopt it. Where capital punishment does not powerfully deter, the empirical predicate for that obligation disappears. Retributivists might continue to argue for capital punishment on other grounds, but we are not retributivists and see no inherent moral necessity for capital 
punishment if it produces little in the way of benefits in the protection of human life. If future work were to overturn the recent evidence that capital punishment deters, that work would also in our view overturn the case for capital punishment altogether.

\section{B. International Variation}

What holds for variation across states within the United States holds a fortiori for variation across liberal democratic polities. The European Union and its member states firmly reject capital punishment as violative of human dignity; more broadly, the United States is one of only a small number of nations that permit capital punishment. How does this bear upon our thesis? The short answer is that we have nothing to say about such polities, because the relevant facts are not yet known. It might turn out that, due to variation in some relevant factor, capital punishment is appropriate for our circumstances but not for the circumstances of (some set of) other polities; nothing in our view excludes this. If capital punishment turns out to deter strongly in some populations, or given some background legal and economic systems, but not otherwise, then the scope of the moral obligation to adopt capital punishment would vary accordingly. Israel does not execute terrorists, in part because of a belief that executions of terrorists would breed more terrorism; if the belief is correct, as seems plausible, then the failure to use capital punishment is correct too. (Those who favor capital punishment on retributive grounds might ask whether they reject Israel's policy.)

\section{Offenders and Offenses}

Other dimensions of variation include differences in classes of offenses (murders for profit versus murders animated by passion) and in classes of offenders (juvenile murders, mentally disabled murders, and so on). As we noted in discussing the argument from slippery slopes, no a priori argument either precludes or mandates extending capital punishment to all such cases, because a priori argument is not helpful here.

Let us consider the example of juvenile offenders. In a recent decision, the Supreme Court held that capital punishment may not be inflicted upon offenders who were under 18 years old at the time of the offense. ${ }^{95}$ Acknowledging the paucity of

\footnotetext{
${ }^{95}$ Roper v. Simmons, 125 S. Ct. 1183, 1198 (2005).
} 
evidence either way, the Court speculated that such offenders are less deterrable than adults. ${ }^{96}$ Below, we will review findings suggesting, by analogy to crimes of passion, that the speculation is mistaken. What if the facts turn out to be otherwise than the Court guessed? Suppose that there turns out to be a significant class of 15-year-old murderers, perhaps predominantly murdering other 15-year-olds; and suppose that relevant data suggested that allowing capital punishment for 15-year-olds would significantly deter those murders.

In our view, there is a strong argument that states would then be morally obligated to extend capital punishment to such cases (bracketing whether such a course would be legally permitted). If the obligation would attach, it is precisely because killing 15-yearolds is morally unacceptable, and because capital punishment would be the best system for reducing overall the number of such killings; only an implausible version of the act/omission distinction would suggest otherwise. On the other hand, suppose that the Court's speculation is correct, and that murders by juveniles turn out to be genuinely undeterrable, perhaps because juveniles are not yet capable of reasoning clearly about the expected costs and benefits of crime, or frequently act out of uncontrollable passion. Then the factual predicate for our view would simply fail to apply.

The same holds true for classes of offenses. The recent work has suggested, contrary to the intuitions of many, that capital punishment may well deter types of murders previously thought undeterrable. ${ }^{97}$ In particular, the frequent conjecture that murders animated by passion are undeterrable turns out to be erroneous. Should future work identify such a category of undeterrable murders, however, our view would straightforwardly entail that capital punishment ought not extend to such cases.

\section{Life-Life Tradeoffs and Beyond}

Every case we have discussed so far involves what we have called life-life tradeoffs: cases in which state execution deters many private executions. A very different set of moral and institutional problems arises when the issue is whether capital punishment should be used to deter serious offenses other than killing. Consider the

\footnotetext{
${ }^{96}$ Id. at 1196.

${ }^{97}$ Shepherd, supra note 21, at 305.
} 
sentence of capital punishment for particularly serious forms of rape, which the Supreme Court invalidated as cruel and unusual punishment. ${ }^{98}$ Apart from constitutional constraints, would states be morally obligated to employ capital punishment if it could be shown, empirically, that each such execution would deter many future rapes?

We have given simple answers to the foregoing questions about variation in regional and international circumstances, and in classes of offenders and offenses, but no simple answers are possible here. The reason is that, unlike the other cases, the harms on the two sides of the ledger are not the same. Where capital punishment of murderers is at issue, the taking of life is the only morally relevant action in the picture, and the state's taking of life is entirely commensurable with the crimes it deters. (This assumes that one rejects, as we did in Part II, the attempt to build the act-omission distinction right into the definition of the relevant action. We have rejected, in other words, the idea that the state's taking of life is itself a morally different act from the "private" taking of life that is made possible by the state's choice of a criminal-justice policy that does not include capital punishment). When other offenses are at issue, additional moral questions of commensurability and of aggregation arise. May the state inflict a permanent deprivation of all personhood (death) upon a few to deter serious, but temporary, deprivations of autonomy (rape) that would otherwise be inflicted upon many? What if the many are children? The moral analysis here will necessarily be more complicated. If a utilitarian or consequentialist framework is used, the effects must be "translated" in some way so as to permit tradeoffs to occur. Suppose that an execution of a rapist would deter thirty rapes; how should capital punishment be evaluated in that event? It is most unclear how to think about these and similar cases; here we mean to bracket such questions entirely.

\section{Conclusion}

We conjecture that something like the following set of views about capital punishment has been and probably still is widespread in the legal academy. Capital punishment does not deter, or at least the evidence that it does so is essentially

\footnotetext{
${ }^{98}$ See Coker v. Georgia, 433 U.S. 584, 598 (1977).
} 
nonexistent ${ }^{99}$; some categories of murders, especially crimes of passion, are undeterrable (at least by capital punishment); ${ }^{100}$ even if capital punishment has a deterrent effect, the effect is marginal, perhaps because of the relatively small number of capital sentences and the long time lags between sentencing and execution; ${ }^{101}$ the system of capital punishment is rife with error and arbitrariness. ${ }^{102}$

The recent evidence raises doubts about all of these views. Capital punishment may well have strong deterrent effects; there is evidence that few categories of murders are inherently undeterrable, even so-called crimes of passion; some studies find extremely large deterrent effects; error and arbitrariness undoubtedly occur, but the evidence of deterrence suggests that prospective murderers are receiving a clear signal.

The moral and legal commentary on capital punishment ought to be sensitive to any significant revision in what we know. Life-life tradeoffs are inescapably involved. In light of recent evidence, a government that settles upon a package of crime-control policies that does not include capital punishment might well seem, at least prima facie, to be both violating the rights and reducing the welfare of its citizens- just as would a state that failed to enact simple environmental measures promising to save a great many lives.

The most common basis for resisting this conclusion, and our principal target here, is some version of the distinction between acts and omissions. Opponents of capital punishment frequently appeal to an intuition that intentional killing by the government and its agents is morally objectionable in a way that simply allowing private killings is not. Whatever the general merits of the distinction between acts and omissions in the moral theory of individual conduct, we think it gets little purchase on questions of governmental policy. Government cannot help but act in ways that affect the actions of citizens; where citizens decide whether or not to kill each other in light of government's policies, it is not clear even as a conceptual matter what it would mean for government not to act. For government to adopt a mix of criminal-justice policies that happens not to include capital punishment is not an "omission" or a "failure to act" in any meaningful sense. Likewise, deontological injunctions against unjustified killing, which we have not

\footnotetext{
${ }^{99}$ See Richard O. Lempert, Desert and Deterrence: An Assessment of the Moral Bases of the Case for Capital Punishment, 79 Mich. L. Rev. 1177, 1222 (1981).

${ }^{100}$ See id. at $1193-94$.

${ }^{101}$ See id. at $1192-93$.

${ }^{102}$ See id. at 1224.
} 
questioned here, are of little help in these settings. Unjustified killing is exactly what capital punishment prevents.

If this argument is correct, it has broad implications, some of which may not be welcomed by advocates of capital punishment. Government engages in countless omissions, many of which threaten people's health and safety; consider the failure to reduce highway fatalities, to regulate greenhouse gas emissions, to prevent domestic violence, to impose further controls on private uses of guns, even to redistribute wealth to those who most need it. Suppose that it is not sensible, in these and other contexts, to characterize government omissions as such, or suppose that even if the characterization is sensible, it lacks moral relevance. If so, then government might well be compelled, on one or another ground, to take steps to protect people against statistical risks, even if those steps impose costs and harms; much will depend on what the facts show. ${ }^{103}$

Any objection to capital punishment, we believe, must rely on something other than abstract injunctions against the taking of life. If the recent evidence of deterrence is shown to be correct, then opponents of capital punishment will face an uphill struggle on moral grounds. If each execution is saving many lives, the harms of capital punishment would have to be very great to justify its abolition, far greater than most critics have heretofore alleged. There is always residual uncertainty in social science and legal policy, and we have attempted to describe, rather than to defend, recent findings here. But if those findings are ultimately shown to be right, capital punishment has a strong claim to being, not merely morally permissible, but morally obligatory, above all from the standpoint of those who wish to protect life.

Readers with comments may address them to:

Professor Cass Sunstein

University of Chicago Law School

1111 East 60th Street

Chicago, IL 60637

csunstei@midway.uchicago.edu

\footnotetext{
${ }^{103}$ For a general attack on the act-omission distinction from a utilitarian perspective, see Jonathan Baron, Judgment Misguided (1998). If our argument is correct, some of Baron's arguments should be appealing to deontologists as well, and his controversial commitment to utilitarianism is not a necessary foundation for his conclusions.
} 


\section{Chicago Working Papers in Law and Economics (Second Series)}

1. William M. Landes, Copyright Protection of Letters, Diaries and Other Unpublished Works: An Economic Approach (July 1991)

2. Richard A. Epstein, The Path to The T.J. Hooper: The Theory and History of Custom in the Law of Tort (August 1991)

3. Cass R. Sunstein, On Property and Constitutionalism (September 1991)

4. Richard A. Posner, Blackmail, Privacy, and Freedom of Contract (February 1992)

5. Randal C. Picker, Security Interests, Misbehavior, and Common Pools (February 1992)

6. Tomas J. Philipson \& Richard A. Posner, Optimal Regulation of AIDS (April 1992)

7. Douglas G. Baird, Revisiting Auctions in Chapter 11 (April 1992)

8. William M. Landes, Sequential versus Unitary Trials: An Economic Analysis (July 1992)

9. William M. Landes \& Richard A. Posner, The Influence of Economics on Law: A Quantitative Study (August 1992)

10. Alan O. Sykes, The Welfare Economics of Immigration Law: A Theoretical Survey With An Analysis of U.S. Policy (September 1992)

11. Douglas G. Baird, 1992 Katz Lecture: Reconstructing Contracts (November 1992)

12. Gary S. Becker, The Economic Way of Looking at Life (January 1993)

13. J. Mark Ramseyer, Credibly Committing to Efficiency Wages: Cotton Spinning Cartels in Imperial Japan (March 1993)

14. Cass R. Sunstein, Endogenous Preferences, Environmental Law (April 1993)

15. Richard A. Posner, What Do Judges and Justices Maximize? (The Same Thing Everyone Else Does) (April 1993)

16. Lucian Arye Bebchuk and Randal C. Picker, Bankruptcy Rules, Managerial Entrenchment, and Firm-Specific Human Capital (August 1993)

17. J. Mark Ramseyer, Explicit Reasons for Implicit Contracts: The Legal Logic to the Japanese Main Bank System (August 1993)

18. William M. Landes and Richard A. Posner, The Economics of Anticipatory Adjudication (September 1993)

19. Kenneth W. Dam, The Economic Underpinnings of Patent Law (September 1993)

20. Alan O. Sykes, An Introduction to Regression Analysis (October 1993)

21. Richard A. Epstein, The Ubiquity of the Benefit Principle (March 1994)

22. Randal C. Picker, An Introduction to Game Theory and the Law (June 1994)

23. William M. Landes, Counterclaims: An Economic Analysis (June 1994)

24. J. Mark Ramseyer, The Market for Children: Evidence from Early Modern Japan (August 1994)

25. Robert H. Gertner and Geoffrey P. Miller, Settlement Escrows (August 1994)

26. Kenneth W. Dam, Some Economic Considerations in the Intellectual Property Protection of Software (August 1994)

27. Cass R. Sunstein, Rules and Rulelessness, (October 1994)

28. David Friedman, More Justice for Less Money: A Step Beyond Cimino (December 1994)

29. Daniel Shaviro, Budget Deficits and the Intergenerational Distribution of Lifetime Consumption (January 1995)

30. Douglas G. Baird, The Law and Economics of Contract Damages (February 1995)

31. Daniel Kessler, Thomas Meites, and Geoffrey P. Miller, Explaining Deviations from the Fifty Percent Rule: A Multimodal Approach to the Selection of Cases for Litigation (March 1995)

32. Geoffrey P. Miller, Das Kapital: Solvency Regulation of the American Business Enterprise (April 1995)

33. Richard Craswell, Freedom of Contract (August 1995)

34. J. Mark Ramseyer, Public Choice (November 1995)

35. Kenneth W. Dam, Intellectual Property in an Age of Software and Biotechnology (November 1995)

36. Cass R. Sunstein, Social Norms and Social Roles (January 1996) 
37. J. Mark Ramseyer and Eric B. Rasmusen, Judicial Independence in Civil Law Regimes:

Econometrics from Japan (January 1996)

38. Richard A. Epstein, Transaction Costs and Property Rights: Or Do Good Fences Make Good

Neighbors? (March 1996)

39. Cass R. Sunstein, The Cost-Benefit State (May 1996)

40. William M. Landes and Richard A. Posner, The Economics of Legal Disputes Over the Ownership of Works of Art and Other Collectibles (July 1996)

41. John R. Lott, Jr. and David B. Mustard, Crime, Deterrence, and Right-to-Carry Concealed

Handguns (August 1996)

42. Cass R. Sunstein, Health-Health Tradeoffs (September 1996)

43. G. Baird, The Hidden Virtues of Chapter 11: An Overview of the Law and Economics of Financially Distressed Firms (March 1997)

44. Richard A. Posner, Community, Wealth, and Equality (March 1997)

45. William M. Landes, The Art of Law and Economics: An Autobiographical Essay (March 1997)

46. Cass R. Sunstein, Behavioral Analysis of Law (April 1997)

47. John R. Lott, Jr. and Kermit Daniel, Term Limits and Electoral Competitiveness: Evidence from California's State Legislative Races (May 1997)

48. Randal C. Picker, Simple Games in a Complex World: A Generative Approach to the Adoption of Norms (June 1997)

49. Richard A. Epstein, Contracts Small and Contracts Large: Contract Law through the Lens of Laissez-Faire (August 1997)

50. Cass R. Sunstein, Daniel Kahneman, and David Schkade, Assessing Punitive Damages (with Notes on Cognition and Valuation in Law) (December 1997)

51. William M. Landes, Lawrence Lessig, and Michael E. Solimine, Judicial Influence: A Citation Analysis of Federal Courts of Appeals Judges (January 1998)

52. John R. Lott, Jr., A Simple Explanation for Why Campaign Expenditures are Increasing: The Government is Getting Bigger (February 1998)

53. Richard A. Posner, Values and Consequences: An Introduction to Economic Analysis of Law (March 1998)

54. Denise DiPasquale and Edward L. Glaeser, Incentives and Social Capital: Are Homeowners Better Citizens? (April 1998)

55. Christine Jolls, Cass R. Sunstein, and Richard Thaler, A Behavioral Approach to Law and Economics (May 1998)

56. John R. Lott, Jr., Does a Helping Hand Put Others At Risk?: Affirmative Action, Police Departments, and Crime (May 1998)

57. Cass R. Sunstein and Edna Ullmann-Margalit, Second-Order Decisions (June 1998)

58. Jonathan M. Karpoff and John R. Lott, Jr., Punitive Damages: Their Determinants, Effects on Firm Value, and the Impact of Supreme Court and Congressional Attempts to Limit Awards (July 1998)

59. $\quad$ Kenneth W. Dam, Self-Help in the Digital Jungle (August 1998)

60. John R. Lott, Jr., How Dramatically Did Women's Suffrage Change the Size and Scope of Government? (September 1998)

61. Kevin A. Kordana and Eric A. Posner, A Positive Theory of Chapter 11 (October 1998)

62. David A. Weisbach, Line Drawing, Doctrine, and Efficiency in the Tax Law (November 1998)

63. Jack L. Goldsmith and Eric A. Posner, A Theory of Customary International Law (November 1998)

64. John R. Lott, Jr., Public Schooling, Indoctrination, and Totalitarianism (December 1998)

65. Cass R. Sunstein, Private Broadcasters and the Public Interest: Notes Toward A "Third Way" (January 1999)

66. Richard A. Posner, An Economic Approach to the Law of Evidence (February 1999)

67. Yannis Bakos, Erik Brynjolfsson, Douglas Lichtman, Shared Information Goods (February 1999)

68. Kenneth W. Dam, Intellectual Property and the Academic Enterprise (February 1999)

69. Gertrud M. Fremling and Richard A. Posner, Status Signaling and the Law, with Particular Application to Sexual Harassment (March 1999)

70. Cass R. Sunstein, Must Formalism Be Defended Empirically? (March 1999) 
71. Jonathan M. Karpoff, John R. Lott, Jr., and Graeme Rankine, Environmental Violations, Legal Penalties, and Reputation Costs (March 1999)

72. Matthew D. Adler and Eric A. Posner, Rethinking Cost-Benefit Analysis (April 1999)

73. John R. Lott, Jr. and William M. Landes, Multiple Victim Public Shooting, Bombings, and Right-toCarry Concealed Handgun Laws: Contrasting Private and Public Law Enforcement (April 1999)

74. Lisa Bernstein, The Questionable Empirical Basis of Article 2's Incorporation Strategy: A Preliminary Study (May 1999)

75. Richard A. Epstein, Deconstructing Privacy: and Putting It Back Together Again (May 1999)

76. William M. Landes, Winning the Art Lottery: The Economic Returns to the Ganz Collection (May 1999)

77. Cass R. Sunstein, David Schkade, and Daniel Kahneman, Do People Want Optimal Deterrence? (June 1999)

78. Tomas J. Philipson and Richard A. Posner, The Long-Run Growth in Obesity as a Function of Technological Change (June 1999)

79. David A. Weisbach, Ironing Out the Flat Tax (August 1999)

80. Eric A. Posner, A Theory of Contract Law under Conditions of Radical Judicial Error (August 1999)

81. David Schkade, Cass R. Sunstein, and Daniel Kahneman, Are Juries Less Erratic than Individuals? Deliberation, Polarization, and Punitive Damages (September 1999)

82. Cass R. Sunstein, Nondelegation Canons (September 1999)

83. Richard A. Posner, The Theory and Practice of Citations Analysis, with Special Reference to Law and Economics (September 1999)

84. Randal C. Picker, Regulating Network Industries: A Look at Intel (October 1999)

85. Cass R. Sunstein, Cognition and Cost-Benefit Analysis (October 1999)

86. Douglas G. Baird and Edward R. Morrison, Optimal Timing and Legal Decisionmaking: The Case of the Liquidation Decision in Bankruptcy (October 1999)

87. Gertrud M. Fremling and Richard A. Posner, Market Signaling of Personal Characteristics (November 1999)

88. Matthew D. Adler and Eric A. Posner, Implementing Cost-Benefit Analysis When Preferences Are Distorted (November 1999)

89. Richard A. Posner, Orwell versus Huxley: Economics, Technology, Privacy, and Satire (November 1999)

90. David A. Weisbach, Should the Tax Law Require Current Accrual of Interest on Derivative Financial Instruments? (December 1999)

91. Cass R. Sunstein, The Law of Group Polarization (December 1999)

92. Eric A. Posner, Agency Models in Law and Economics (January 2000)

93. Karen Eggleston, Eric A. Posner, and Richard Zeckhauser, Simplicity and Complexity in Contracts (January 2000)

94. Douglas G. Baird and Robert K. Rasmussen, Boyd's Legacy and Blackstone's Ghost (February 2000)

95. David Schkade, Cass R. Sunstein, Daniel Kahneman, Deliberating about Dollars: The Severity Shift (February 2000)

96. Richard A. Posner and Eric B. Rasmusen, Creating and Enforcing Norms, with Special Reference to Sanctions (March 2000)

97. Douglas Lichtman, Property Rights in Emerging Platform Technologies (April 2000)

98. Cass R. Sunstein and Edna Ullmann-Margalit, Solidarity in Consumption (May 2000)

99. David A. Weisbach, An Economic Analysis of Anti-Tax Avoidance Laws (May 2000, revised May 2002)

100. Cass R. Sunstein, Human Behavior and the Law of Work (June 2000)

101. William M. Landes and Richard A. Posner, Harmless Error (June 2000)

102. Robert H. Frank and Cass R. Sunstein, Cost-Benefit Analysis and Relative Position (August 2000)

103. Eric A. Posner, Law and the Emotions (September 2000)

104. Cass R. Sunstein, Cost-Benefit Default Principles (October 2000) 
105. Jack Goldsmith and Alan Sykes, The Dormant Commerce Clause and the Internet (November 2000)

106. Richard A. Posner, Antitrust in the New Economy (November 2000)

107. Douglas Lichtman, Scott Baker, and Kate Kraus, Strategic Disclosure in the Patent System (November 2000)

108. Jack L. Goldsmith and Eric A. Posner, Moral and Legal Rhetoric in International Relations: A Rational Choice Perspective (November 2000)

109. William Meadow and Cass R. Sunstein, Statistics, Not Experts (December 2000)

110. Saul Levmore, Conjunction and Aggregation (December 2000)

111. Saul Levmore, Puzzling Stock Options and Compensation Norms (December 2000)

112. Richard A. Epstein and Alan O. Sykes, The Assault on Managed Care: Vicarious Liability, Class Actions and the Patient's Bill of Rights (December 2000)

113. William M. Landes, Copyright, Borrowed Images and Appropriation Art: An Economic Approach (December 2000)

114. Cass R. Sunstein, Switching the Default Rule (January 2001)

115. George G. Triantis, Financial Contract Design in the World of Venture Capital (January 2001)

116. Jack Goldsmith, Statutory Foreign Affairs Preemption (February 2001)

117. Richard Hynes and Eric A. Posner, The Law and Economics of Consumer Finance (February 2001)

118. Cass R. Sunstein, Academic Fads and Fashions (with Special Reference to Law) (March 2001)

119. Eric A. Posner, Controlling Agencies with Cost-Benefit Analysis: A Positive Political Theory Perspective (April 2001)

120. Douglas G. Baird, Does Bogart Still Get Scale? Rights of Publicity in the Digital Age (April 2001)

121. Douglas G. Baird and Robert K. Rasmussen, Control Rights, Priority Rights and the Conceptual Foundations of Corporate Reorganization (April 2001)

122. David A. Weisbach, Ten Truths about Tax Shelters (May 2001)

123. William M. Landes, What Has the Visual Arts Rights Act of 1990 Accomplished? (May 2001)

124. Cass R. Sunstein, Social and Economic Rights? Lessons from South Africa (May 2001)

125. Christopher Avery, Christine Jolls, Richard A. Posner, and Alvin E. Roth, The Market for Federal Judicial Law Clerks (June 2001)

126. Douglas G. Baird and Edward R. Morrison, Bankruptcy Decision Making (June 2001)

127. Cass R. Sunstein, Regulating Risks after ATA (June 2001)

128. Cass R. Sunstein, The Laws of Fear (June 2001)

129. Richard A. Epstein, In and Out of Public Solution: The Hidden Perils of Property Transfer (July 2001)

130. Randal C. Picker, Pursuing a Remedy in Microsoft: The Declining Need for Centralized Coordination in a Networked World (July 2001)

131. Cass R. Sunstein, Daniel Kahneman, David Schkade, and Ilana Ritov, Predictably Incoherent Judgments (July 2001)

132. Eric A. Posner, Courts Should Not Enforce Government Contracts (August 2001)

133. Lisa Bernstein, Private Commercial Law in the Cotton Industry: Creating Cooperation through Rules, Norms, and Institutions (August 2001)

134. Richard A. Epstein, The Allocation of the Commons: Parking and Stopping on the Commons (August 2001)

135. Cass R. Sunstein, The Arithmetic of Arsenic (September 2001)

136. Eric A. Posner, Richard Hynes, and Anup Malani, The Political Economy of Property Exemption Laws (September 2001)

137. Eric A. Posner and George G. Triantis, Covenants Not to Compete from an Incomplete Contracts Perspective (September 2001)

138. Cass R. Sunstein, Probability Neglect: Emotions, Worst Cases, and Law (November 2001)

139. Randall S. Kroszner and Philip E. Strahan, Throwing Good Money after Bad? Board Connections and Conflicts in Bank Lending (December 2001)

140. Alan O. Sykes, TRIPs, Pharmaceuticals, Developing Countries, and the Doha "Solution" (February 2002) 
141. Edna Ullmann-Margalit and Cass R. Sunstein, Inequality and Indignation (February 2002)

142. Daniel N. Shaviro and David A. Weisbach, The Fifth Circuit Gets It Wrong in Compaq v. Commissioner (February 2002) (Published in Tax Notes, January 28, 2002)

143. Warren F. Schwartz and Alan O. Sykes, The Economic Structure of Renegotiation and Dispute Resolution in the WTO/GATT System (March 2002, Journal of Legal Studies 2002)

144. Richard A. Epstein, HIPAA on Privacy: Its Unintended and Intended Consequences (March 2002, forthcoming Cato Journal, summer 2002)

145. David A. Weisbach, Thinking Outside the Little Boxes (March 2002, Texas Law Review)

146. Eric A. Posner, Economic Analysis of Contract Law after Three Decades: Success or Failure (March 2002)

147. Randal C. Picker, Copyright as Entry Policy: The Case of Digital Distribution (April 2002, The Antitrust Bulletin)

148. David A. Weisbach, Taxes and Torts in the Redistribution of Income (April 2002, Coase Lecture February 2002)

149. Cass R. Sunstein, Beyond the Precautionary Principle (April 2002)

150. Robert W. Hahn and Cass R. Sunstein, A New Executive Order for Improving Federal Regulation? Deeper and Wider Cost-Benefit Analysis (April 2002)

151. Douglas Lichtman, Copyright as a Rule of Evidence (May 2002, updated January 2003)

152. Richard A. Epstein, Steady the Course: Property Rights in Genetic Material (May 2002; revised March 2003)

153. Jack Goldsmith and Cass R. Sunstein, Military Tribunals and Legal Culture: What a Difference Sixty Years Makes (June 2002)

154. William M. Landes and Richard A. Posner, Indefinitely Renewable Copyright (July 2002)

155. Anne Gron and Alan O. Sykes, Terrorism and Insurance Markets: A Role for the Government as Insurer? (July 2002)

156. Cass R. Sunstein and Adrian Vermeule, Interpretation and Institutions (July 2002)

157. Cass R. Sunstein, The Rights of Animals: A Very Short Primer (August 2002)

158. Cass R. Sunstein, Avoiding Absurdity? A New Canon in Regulatory Law (with Notes on Interpretive Theory) (August 2002)

159. Randal C. Picker, From Edison to the Broadcast Flag: Mechanisms of Consent and Refusal and the Propertization of Copyright (September 2002)

160. Eric A. Posner, A Theory of the Laws of War (September 2002)

161 Eric A. Posner, Probability Errors: Some Positive and Normative Implications for Tort and Contract Law (September 2002)

162. Lior Jacob Strahilevitz, Charismatic Code, Social Norms, and the Emergence of Cooperation on the File-Swapping Networks (September 2002)

163. David A. Weisbach, Does the X-Tax Mark the Spot? (September 2002)

164. Cass R. Sunstein, Conformity and Dissent (September 2002)

165. Cass R. Sunstein, Hazardous Heuristics (October 2002)

166. Douglas Lichtman, Uncertainty and the Standard for Preliminary Relief (October 2002)

167. Edward T. Swaine, Rational Custom (November 2002)

168. Julie Roin, Truth in Government: Beyond the Tax Expenditure Budget (November 2002)

169. Avraham D. Tabbach, Criminal Behavior: Sanctions and Income Taxation: An Economic Analysis (November 2002)

170. Richard A. Epstein, In Defense of “Old” Public Health: The Legal Framework for the Regulation of Public Health (December 2002)

171. Richard A. Epstein, Animals as Objects, or Subjects, of Rights (December 2002)

172. David A. Weisbach, Taxation and Risk-Taking with Multiple Tax Rates (December 2002)

173. Douglas G. Baird and Robert K. Rasmussen, The End of Bankruptcy (December 2002)

174. Richard A. Epstein, Into the Frying Pan: Standing and Privity under the Telecommunications Act of 1996 and Beyond (December 2002)

175. Douglas G. Baird, In Coase's Footsteps (January 2003) 
176. David A. Weisbach, Measurement and Tax Depreciation Policy: The Case of Short-Term Assets (January 2003)

177. Randal C. Picker, Understanding Statutory Bundles: Does the Sherman Act Come with the 1996 Telecommunications Act? (January 2003)

178. Douglas Lichtman and Randal C. Picker, Entry Policy in Local Telecommunications: Iowa Utilities and Verizon (January 2003)

179. William Landes and Douglas Lichtman, Indirect Liability for Copyright Infringement: An Economic Perspective (February 2003)

180. Cass R. Sunstein, Moral Heuristics (March 2003)

181. Amitai Aviram, Regulation by Networks (March 2003)

182. Richard A. Epstein, Class Actions: Aggregation, Amplification and Distortion (April 2003)

183. Richard A. Epstein, The "Necessary" History of Property and Liberty (April 2003)

184. Eric A. Posner, Transfer Regulations and Cost-Effectiveness Analysis (April 2003)

185. Cass R. Sunstein and Richard H. Thaler, Libertarian Paternalizm Is Not an Oxymoron (May 2003)

186. Alan O. Sykes, The Economics of WTO Rules on Subsidies and Countervailing Measures (May 2003)

187. Alan O. Sykes, The Safeguards Mess: A Critique of WTO Jurisprudence (May 2003)

188. Alan O. Sykes, International Trade and Human Rights: An Economic Perspective (May 2003)

189. Saul Levmore and Kyle Logue, Insuring against Terrorism - and Crime (June 2003)

190. Richard A. Epstein, Trade Secrets as Private Property: Their Constitutional Protection (June 2003)

191. Cass R. Sunstein, Lives, Life-Years, and Willingness to Pay (June 2003)

192. Amitai Aviram, The Paradox of Spontaneous Formation of Private Legal Systems (July 2003)

193. Robert Cooter and Ariel Porat, Decreasing Liability Contracts (July 2003)

194. David A. Weisbach and Jacob Nussim, The Integration of Tax and Spending Programs (September 2003)

195. William L. Meadow, Anthony Bell, and Cass R. Sunstein, Statistics, Not Memories: What Was the Standard of Care for Administering Antenatal Steroids to Women in Preterm Labor between 1985 and 2000? (September 2003)

196. Cass R. Sunstein, What Did Lawrence Hold? Of Autonomy, Desuetude, Sexuality, and Marriage (September 2003)

197. Randal C. Picker, The Digital Video Recorder: Unbundling Advertising and Content (September 2003)

198. Cass R. Sunstein, David Schkade, and Lisa Michelle Ellman, Ideological Voting on Federal Courts of Appeals: A Preliminary Investigation (September 2003)

199. Avraham D. Tabbach, The Effects of Taxation on Income Producing Crimes with Variable Leisure Time (October 2003)

200. Douglas Lichtman, Rethinking Prosecution History Estoppel (October 2003)

201. Douglas G. Baird and Robert K. Rasmussen, Chapter 11 at Twilight (October 2003)

202. David A. Weisbach, Corporate Tax Avoidance (January 2004)

203. David A. Weisbach, The (Non)Taxation of Risk (January 2004)

204. Richard A. Epstein, Liberty versus Property? Cracks in the Foundations of Copyright Law (April 2004)

205. Lior Jacob Strahilevitz, The Right to Destroy (January 2004)

206. Eric A. Posner and John C. Yoo, A Theory of International Adjudication (February 2004)

207. Cass R. Sunstein, Are Poor People Worth Less Than Rich People? Disaggregating the Value of Statistical Lives (February 2004)

208. Richard A. Epstein, Disparities and Discrimination in Health Care Coverage; A Critique of the Institute of Medicine Study (March 2004)

209. Richard A. Epstein and Bruce N. Kuhlik, Navigating the Anticommons for Pharmaceutical Patents: Steady the Course on Hatch-Waxman (March 2004)

210. Richard A. Esptein, The Optimal Complexity of Legal Rules (April 2004)

211. Eric A. Posner and Alan O. Sykes, Optimal War and Jus Ad Bellum (April 2004)

212. Alan O. Sykes, The Persistent Puzzles of Safeguards: Lessons from the Steel Dispute (May 2004) 
213. Luis Garicano and Thomas N. Hubbard, Specialization, Firms, and Markets: The Division of Labor within and between Law Firms (April 2004)

214. Luis Garicano and Thomas N. Hubbard, Hierarchies, Specialization, and the Utilization of Knowledge: Theory and Evidence from the Legal Services Industry (April 2004)

215. James C. Spindler, Conflict or Credibility: Analyst Conflicts of Interest and the Market for Underwriting Business (July 2004)

216. Alan O. Sykes, The Economics of Public International Law (July 2004)

217. Douglas Lichtman and Eric Posner, Holding Internet Service Providers Accountable (July 2004)

218. Shlomo Benartzi, Richard H. Thaler, Stephen P. Utkus, and Cass R. Sunstein, Company Stock, Market Rationality, and Legal Reform (July 2004)

219. Cass R. Sunstein, Group Judgments: Deliberation, Statistical Means, and Information Markets (August 2004, revised October 2004)

220. Cass R. Sunstein, Precautions against What? The Availability Heuristic and Cross-Cultural Risk Perceptions (August 2004)

221. M. Todd Henderson and James C. Spindler, Corporate Herroin: A Defense of Perks (August 2004)

222. Eric A. Posner and Cass R. Sunstein, Dollars and Death (August 2004)

223. Randal C. Picker, Cyber Security: Of Heterogenity and Autarky (August 2004)

224. Randal C. Picker, Unbundling Scope-of-Permission Goods: When Should We Invest in Reducing Entry Barriers? (September 2004)

225. Christine Jolls and Cass R. Sunstein, Debiasing through Law (September 2004)

226. Richard A. Posner, An Economic Analysis of the Use of Citations in the Law (2000)

227. Cass R. Sunstein, Cost-Benefit Analysis and the Environment (October 2004)

228. Kenneth W. Dam, Cordell Hull, the Reciprocal Trade Agreement Act, and the WTO (October 2004)

229. Richard A. Posner, The Law and Economics of Contract Interpretation (November 2004)

230. Lior Jacob Strahilevitz, A Social Networks Theory of Privacy (December 2004)

231. Cass R. Sunstein, Minimalism at War (December 2004)

232. Douglas Lichtman, How the Law Responds to Self-Help (December 2004)

233. Eric A. Posner, The Decline of the International Court of Justice (December 2004)

234. Eric A. Posner, Is the International Court of Justice Biased? (December 2004)

235. Alan O. Sykes, Public vs. Private Enforcement of International Economic Law: Of Standing and Remedy (February 2005)

236. Dougals G. Baird and Edward R. Morrison, Serial Entrepreneurs and Small Business Bankruptcies (March 2005)

237. Eric A. Posner, There Are No Penalty Default Rules in Contract Law (March 2005)

238. Randal C. Picker, Copyright and the DMCA: Market Locks and Technological Contracts (March 2005)

239. Cass R. Sunstein and Adrian Vermeule, Is Capital Punishment Morally Required? The Relevance of Life-Life Tradeoffs (March 2005) 